\title{
2. HIGH-RESOLUTION SEISMIC STUDIES AND SITE SURVEY RESULTS NEAR DEEP SEA DRILLING PROJECT SITES 576 AND 578, NORTHWEST PACIFIC ${ }^{1}$
}

\author{
Robert D. Jacobi, SUNY at Buffalo and Lamont-Doherty Geological Observatory of Columbia University \\ and \\ Dennis E. Hayes and John E. Damuth, Lamont-Doherty Geological Observatory of Columbia University²
}

\begin{abstract}
The seafloor near Deep Sea Drilling Project Site 576 (study Area $E_{2}$ ) has a strong northwest to southeast lineation, parallel to the strike of the Mesozoic magnetic lineations. High-resolution $(3.5-\mathrm{kHz})$ seismic profiles show four prominent reflectors $\left(R_{2}-R_{5}\right)$. Two strong, continuous reflectors $\left(R_{2}\right.$ and $\left.R_{3}\right)$ overlie a semitransparent section. These reflectors correspond to an $\sim 1.3$ m.y. old volcanic ash and an $\sim 7.2$ m.y. old horizon. Reflector $R_{4}$ is a discontinuous reflector within the semitransparent section and is $\sim 25 \mathrm{~m}$.y. old. Reflector $R_{5}$ corresponds to $\sim 70-\mathrm{m}$. $y$.-old carbonate turbidites in bathymetric lows and to pelagic carbonates or cherts in bathymetric highs. Isopach maps of all seismic intervals between these reflectors reveal local thinning and thickening and can be used to measure variations in sediment-accumulation rate. The local sediment distribution suggests that bottom water has flowed southeast or southwest across Area $\mathrm{E}_{2}$ for the past 70 m.y. This direction is counter to the present net flow of the Pacific Bottom Water and may indicate the existence of a persistent local bottom gyre caused by bathymetric barriers to the west, north, and east of Area $E_{2}$. Dramatic thinning of all seismic intervals in the northeast corner of Area $\mathrm{E}_{2}$ may be related to constricted Pacific Bottom Water accelerating through a gap in the barrier. Anomalous sedimentation suggests that the bottom currents were relatively sluggish from $\sim 25$ to $7 \mathrm{~m}$.y. ago. All seismic intervals reveal very small mass-wasting features; these features are more prevalent in intervals $R_{1}-R_{2}$ and $R_{4}-R_{5}$.

The seafloor around Site 578 (study Area $B_{1}$ ) has an east-west lineation that also parallels Mesozoic lineations. The local relief is low, less than $80 \mathrm{~m}$. High-resolution seismic profiles show several continuous, parallel reflectors that generally correspond to volcanic ash layers: Reflectors $R_{2}\left(\sim 0.47\right.$ m.y. ago), $R_{3}\left(\sim 0.97\right.$ m.y. ago), $R_{4}\left(\sim 2.44\right.$ m.y. ago), $R_{5}$ (5-6 m.y. ago), and $R_{6}$. All reflector intervals increase dramatically (roughly 10 times) in thickness over a south-north distance of only $80 \mathrm{~km}$. This abrupt increase appears to mark a major boundary separating a province with uniformly high sedimentation rates (typically about $50 \mathrm{~mm} / 1000 \mathrm{yr}$. in the upper intervals) to the north from a large province with relatively low sedimentation rates (typically about $5-10 \mathrm{~mm} / 1000 \mathrm{yr}$ ) to the south. The sedimentation boundary has remained virtually stationary for $\sim 6 \mathrm{~m}$.y. and perhaps for more than $20 \mathrm{~m}$.y. Although the sharpness and spatial stability of the boundary remain an enigma, we believe that the sedimentation boundary is the consequence of bottom-water flow modulating an otherwise more gradual north-south sedimentation gradient. South of Area $\mathrm{B}_{1}$, sedimentation anomalies indicate that the Pacific Bottom Water flows north or northwest, but within Area $\mathbf{B}_{1}$, sedimentation variations suggest an eastward flow. A period of higher velocity flow between $\sim 2.44$ and 5-6 m.y. ago $\left(R_{4}-R_{5}\right.$ times) is consistent with results from Area $\mathrm{E}_{2}$, indicating that bottom-water velocity has also apparently increased there since $\sim 7$ m.y. ago.
\end{abstract}

\section{INTRODUCTION}

The Northwest Pacific Basin is bounded on the south by the Mid-Pacific Seamounts, on the west and north by the Japan-Kuril-Aleutian trench system, and on the east by the Emperor and Hawaiian seamount chains (Fig. 1). The scarcity of ship tracks compared to the immensity of the Northwest Pacific Basin has precluded all but regional studies of the basin. The bathymetry has been mapped by Chase et al. (1971), Iwabuchi (1979), and Udintsev (1980). M-sequence magnetic lineations, indicating crust of late Mesozoic age, have been mapped throughout most of the Northwest Pacific (e.g., Larson and Hilde, 1975; Larson et al., 1983).

Regional piston-core studies of the upper $10-20 \mathrm{~m}$ of sediment show that two distinct sediment types predom-

\footnotetext{
${ }^{1}$ Heath, G. R., Burckle, L. H., et al., Init. Repts. DSDP, 86: Washington (U.S. Govt. Printing Office).

${ }^{2}$ Addresses: (Jacobi) Department of Geological Sciences, SUNY at Buffalo, 4240 Ridge Lea Road, Amherst, NY 14226 and Lamont-Doherty Geological Observatory of Columbia University, Palisades, NY 10964; (Hayes) Lamont-Doherty Geological Observatory of Columbia University, Palisades, NY 10964; (Damuth, present address) Mobil Research \& Development Corp., Dallas Research Laboratory, P.O. Box 819047, Dallas, TX 75381.
}

inate in seafloor depths greater than $5000 \mathrm{~m}$ : brown clay in the southeast and siliceous clays and oozes in the northwest (e.g., Horn et al., 1970; Damuth et al., 1983). Volcanic ash layers are prevalent in the upper parts of the piston cores raised near the Japan/Kuril arcs (Horn et al., 1969; Hays and Ninkovich, 1970; Ninkovich and Robertson, 1975). Deeper sediment sections were studied at 12 previously drilled Deep Sea Drilling Project (DSDP) sites (see inside cover, this volume). At these sites, the base of the siliceous clay and ooze is generally middle to late Miocene in age, whereas the base of the brown clay is generally Late Cretaceous in age. Upper Cretaceous chert interbedded with porcellanite and brown clay usually comprises the sedimentary section beneath the homogeneous brown clays (e.g., Damuth et al., 1983).

Regional studies of bottom-water circulation show that the dominant bottom-water mass in the northwest $\mathrm{Pa}$ cific is Pacific Bottom Water (PBW) (Reid and Lynn, 1971; Warren, 1973; Gordon and Gerard, 1970; Craig and Gordon, 1965, Mantyla, 1975). This bottom water flows northward into the Central Pacific through the Samoan Passage (Reid and Lonsdale, 1974; Lonsdale and Spiess, 1977) and enters the Northwest Pacific Basin 


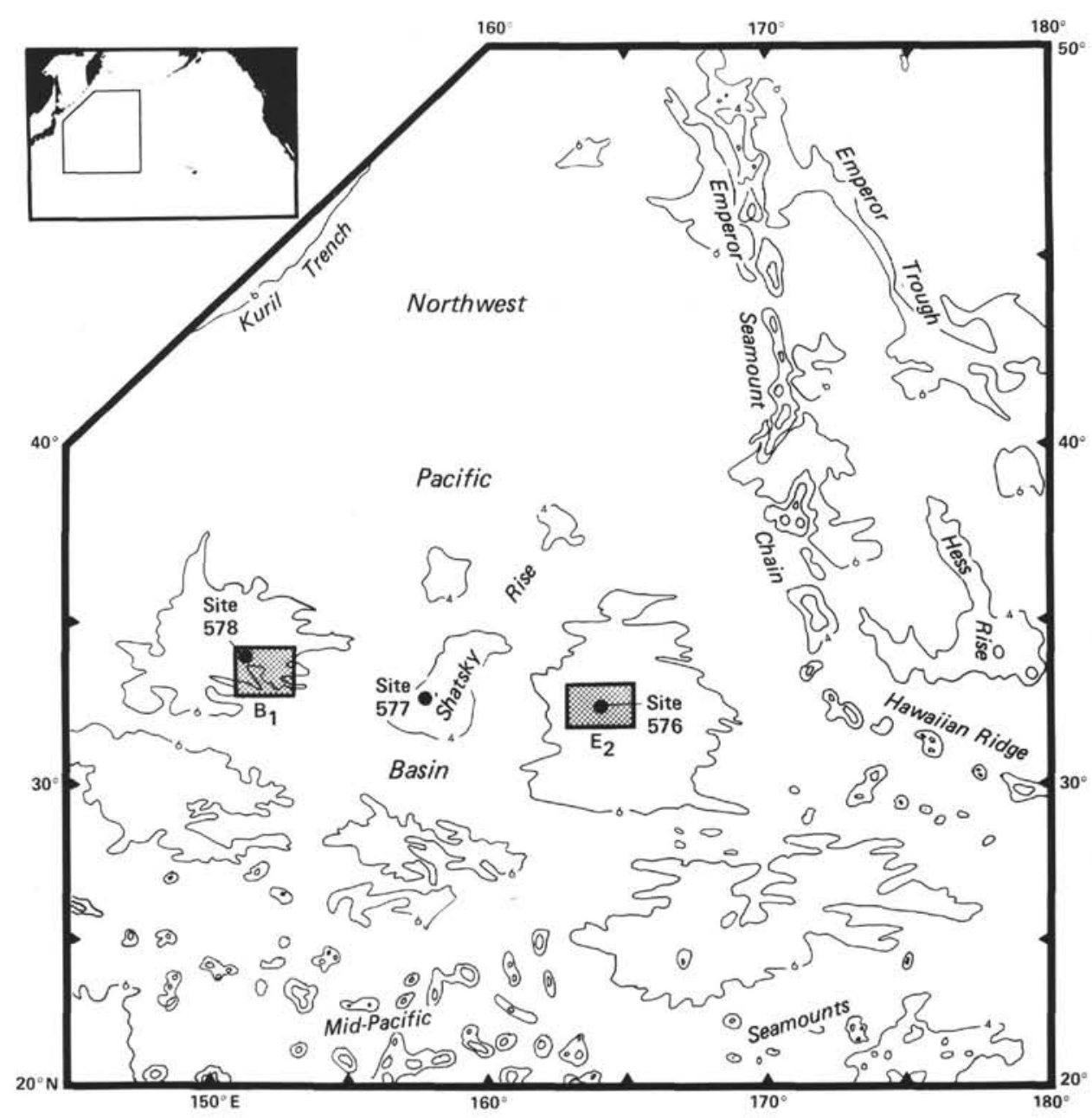

Figure 1. Location of study Areas $E_{2}$ (DSDP Site 576) and $B_{1}$ (DSDP Site 578). Generalized bathymetric contours (2-km contour interval) are redrawn from General Bathymetric Chart of the Oceans (GEBCO) Maps 5-06 (Iwabuchi, 1979) and 5-02 (Udintsev, 1980). Figure is after Damuth et al., 1983.

through deeps between the Mid-Pacific seamounts (Mantyla, 1975; Lonsdale and Smith, 1980). Two branches of the PBW flow through the Northwest Pacific Basin: (1) the western branch, which flows into and northeast along the Japan Trench and (2) the eastern branch, which generally flows northeast from east of the Shatsky Rise to the Emperor Seamount Chain (e.g., Gordon and Gerard, 1970; Mantyla, 1975).

Damuth et al. (1983) conducted echogram studies in order to define the sedimentation processes of the entire basin and to evaluate the potential of selected study sites for subseabed disposal of high-level nuclear waste. In the southeast, transparent sediment (with a few reflectors near the top) overlies a strong prolonged reflector (echo Type II, Damuth et al., 1983). In contrast, continuous, multiple reflectors occur in the northwest (echo Type I; Damuth et al., 1983). Although the areal extent of these two echo types corresponds very generally to the areal extent of the two predominant sediment types (brown clay and siliceous clay), most of the multiple reflectors probably correspond to volcanic ash layers. Two large areas with echo types characteristic of relatively fast bottomwater flow occur: (1) along the north side of the Mid-Pacific Seamounts where the PBW enters the Northwest Pa- cific Basin and (2) west of the Emperor Seamount Chain and north of the Shatsky Rise.

In 1980, Vema Cruise V3612 surveyed in detail three $\sim 1^{\circ} \times 1^{\circ}$ (latitude and longitude) candidate areas (designated $\mathrm{B}_{1}, \mathrm{E}_{2}$, and $\mathrm{C}_{1}$ ) to study further the subseabed option for disposal of high-level nuclear waste (Damuth et al., 1980). Area $E_{2}$ is located east of the Shatsky Rise on oceanic crust of Early Cretaceous age $(\sim 130$ m.y. ago; magnetic Lineation M-13). This area has subdued seafloor relief with a Type II echo character. Area $B_{1}$ is located west of the Shatsky Rise on oceanic crust of Late Jurassic age ( $\sim 150$ m.y. ago; magnetic Lineation M-21 or M-23/M-25). This area has subdued bathymetry and a Type I echo character. Site 576 was drilled in Area $\mathrm{E}_{2}$ and Site 578 in Area $B_{1}$ during DSDP Leg 86 (Fig. 1).

During Vema Cruise 3612, we recovered eight piston cores and conducted five heat-flow and six sonobuoy refraction experiments at Area $\mathrm{E}_{2}$ (Fig. 2, Tables 1-3). All the cores contained brown clay (Table 1); the digitized heat flow values (DHF) were typically $\sim 55 \mathrm{~mW} / \mathrm{m}^{2} \mathrm{ex}-$ cept in the northeastern part of Area $\mathrm{E}_{2}$, where DHF Station 55 had a higher heat flow of $78 \mathrm{~mW} / \mathrm{m}^{2}$ (Table 2). Essentially linear thermal gradients were seen throughout (except at DHF Station 55, Hayes et al., 1983) and 


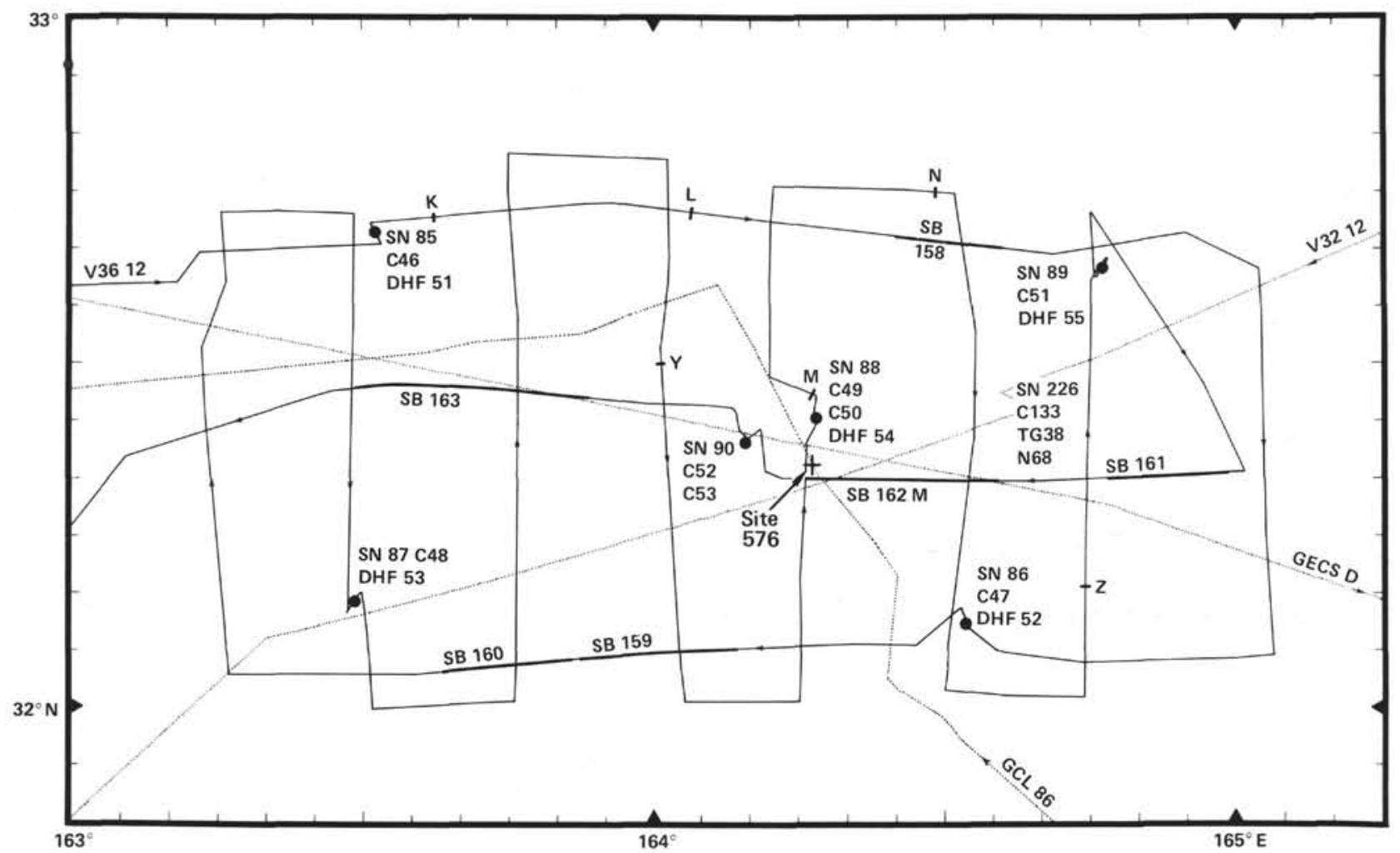

Figure 2. Cruise track lines and station location index map for study Area $E_{2}$ (after Damuth et al., 1980 and Hayes et al., 1982); track identification as follows: $\mathrm{V}=$ Vema, $\mathrm{GCL}=$ Glomar Challenger, $\mathrm{GECS}=$ Geosecs cruise. Sonobuoy $(\mathrm{SB})$ and ship station (SN) locations are shown $(\mathrm{C}=$ core, $\mathrm{DHF}=$ digital heat-flow measurement, $\mathrm{N}=$ nephelometer measurement, $\mathrm{TG}=$ thermograd measurement $)$. The $\sim 100-\mathrm{Hz}$ seismic reflection Profile $\mathrm{Y}-\mathrm{Z}$ is shown in Figure 3; 3.5-kHz echogram Profiles $\mathrm{K}-\mathrm{L}$ and $\mathrm{M}-\mathrm{N}$ are shown in Figure 6. Location of DSDP Site 576 is shown.

argue against any significant recent erosion, high-velocity bottom-water flow, or hydrothermal circulation within the sediments for the area as a whole. Single-channel $(\sim 100 \mathrm{~Hz})$ seismic-reflection profiles collected throughout Area $\mathrm{E}_{2}$ reveal a three-part seismic section (Fig. 3): Unit I, a thin, relatively transparent section (brown clay layer); Unit II, an underlying, more reverberant section (carbonate and chert interbedded with brown clay); and Unit III, oceanic basement. The sonobuoy studies show that the sedimentary layer is $\sim 0.5-\mathrm{km}$ thick. Oceanic Layer 2 extends to $\sim 8.3 \mathrm{~km}$ below sea level (bsl), and Moho lies at $10.1 \mathrm{~km}$ bsl (Table 3).

At Area $B_{1}$, we raised six piston cores and conducted four heat-flow and five sonobuoy experiments (Fig. 4, Tables 1-3). The cores are predominantly gray pelagic to siliceous clay with a brown clay layer at the top (Table 1). The heat-flow values range from $\sim 43$ to $57 \mathrm{~mW} / \mathrm{m}^{2}$ (Table 2). All thermal gradients were linear except at DHF Station 47, where the nonlinear gradient could be caused by recent erosion or bottom-current fluctuation. Single-channel $(\sim 100 \mathrm{~Hz})$ seismic-reflection profiles were collected throughout the area. The three-part seismic section consists of an upper unit (I) of relatively transparent siliceous and brown clay, a more reverberant middle unit (II) of carbonate and chert interbedded with brown clay, and a lower unit (III) consisting of oceanic basement (Fig. 5). The upper unit exhibits dramatic northward thickening. The sonobuoy studies show that the total sediment layer increases in thickness from $0.36 \mathrm{~km}$ in the south to $0.63+\mathrm{km}$ in the northeast. Layer 2 extends to $8.09 \mathrm{~km}$ bsl, and the Moho lies at $\sim 10.66 \mathrm{~km}$ bsl (Table 3 ).

This chapter presents geophysical survey results of study Areas $E_{2}$ and $B_{1}$ and focuses on the detailed bathymetry and near-surface sediment distribution maps primarily derived from $3.5-\mathrm{kHz}$ echograms from Vema Cruise 3612. Determining areal variations in sedimentaccumulation rates and the factors that may be controlling the rates is the primary goal of our study. In our discussion, the terms "sedimentation rate" and "sediment-accumulation rate" are used synonymously, recognizing that the two are not necessarily equivalent.

Although various factors may contribute to the present sediment disposition, systematic regional variations in sedimentation in the mid-gyre regions probably record significant fluctuations in bottom-water circulation. We therefore use the following simple model (e.g., Roberts et al., 1974) to interpret the major sediment-distribution patterns in terms of the present and past bottom-water circulation in Areas $E_{2}$ and $B_{1}$. It is commonly assumed that bottom water flowing past bathymetric highs will result in sediment thinning (e.g., moats) on their up-current sides and sediment thickening (drifts) on their downcurrent sides. Furthermore, looking downstream, the Coriolis force will accelerate the flow to the left of an obstruction and deaccelerate the flow to the right of it (in the Northern Hemisphere). Preferential sediment thinning and thickening should occur accordingly as a con- 
Table 1. General description and location of cores raised from study Areas $E_{2}$ and $B_{1}$ on Cruise V3612

\begin{tabular}{|c|c|c|c|c|}
\hline Area & Core & $\begin{array}{l}\text { Core location } \\
\text { (lat., long.) }\end{array}$ & $\begin{array}{l}\text { Length } \\
\text { of core } \\
(\mathrm{cm})\end{array}$ & General description \\
\hline $\mathrm{E}_{2}$ & $\mathrm{~V} 36 / 12-\mathrm{C} 46$ & $32^{\circ} 41.12^{\prime} \mathrm{N}, 163^{\circ} 31.7^{\prime} \mathrm{E}$ & 1265 & $\begin{array}{l}\text { Yellowish brown silt above } 2 \mathrm{~cm} \text {. Generally yellowish brown mottled clayey silt to silty clay below } \\
2 \mathrm{~cm} \text {. Two yellowish brown silt layers at } 623-633 \mathrm{~cm} \text { and } 920-968 \mathrm{~cm} \text {. One volcanic ash layer at } \\
1105-1113 \mathrm{~cm} \text {. }\end{array}$ \\
\hline $\mathrm{E}_{2}$ & $\mathrm{~V} 36 / 12-\mathrm{C} 47$ & $32^{\circ} 05.95^{\prime} \mathrm{N}, 164^{\circ} 32^{\prime} \mathrm{E}$ & 1262 & $\begin{array}{l}\text { Generally brown to yellowish brown mottled clayey silt to silty clay. Brown to yellowish brown silt } \\
\text { above } 35 \mathrm{~cm} \text { and below } 904 \mathrm{~cm} \text {. }\end{array}$ \\
\hline $\mathrm{E}_{2}$ & $\mathrm{~V} 36 / 12-\mathrm{C} 48$ & $32^{\circ} 09^{\prime} \mathrm{N}, 163^{\circ} 29^{\prime} \mathrm{E}$ & 1268.5 & $\begin{array}{l}\text { Yellowish brown silt with some laminations 0-91 cm. Yellowish brown mottled clayey silt to silty } \\
\text { clay: } 91-627 \mathrm{~cm} \text { and } 1065-1224 \mathrm{~cm} \text {. Yellowish brown mottled silt: } 627-1065 \mathrm{~cm} \text { (coarse grained } \\
\text { at } 674-726 \mathrm{~cm} \text { ) and below } 1224 \mathrm{~cm} \text {. One volcanic ash layer at } 1060-1065 \mathrm{~cm} \text {. }\end{array}$ \\
\hline $\mathrm{E}_{2}$ & $\mathrm{~V} 36 / 12-\mathrm{C} 49$ & $32^{\circ} 24^{\prime} \mathrm{N}, 164^{\circ} 16^{\prime} \mathrm{E}$ & 1192.5 & $\begin{array}{l}\text { Generally yellowish brown to brown clayey silt to silty clay above } 552 \mathrm{~cm} \text {, between } 670-690,780- \\
820 \text {, and } 859-974 \mathrm{~cm} \text {; laminations present at } 24-35 \mathrm{~cm} \text {. Yellowish brown mottled silt at } 552- \\
648,690-780,842-859,977-992 \text {, and } 1014-1164 \mathrm{~cm} \text {. One volcanic ash layer at } 974-977 \mathrm{~cm} \text {. }\end{array}$ \\
\hline$E_{2}$ & $\mathrm{~V} 36 / 12-\mathrm{GC} 50$ & $32^{\circ} 24^{\prime} \mathrm{N}, 164^{\circ} 16^{\prime} \mathrm{E}$ & 289 & Same as above. \\
\hline $\mathrm{E}_{2}$ & $\mathrm{~V} 36 / 12-\mathrm{C} 51$ & $32^{\circ} 24^{\prime} \mathrm{N}, 164^{\circ} 46^{\prime} \mathrm{E}$ & 1271 & $\begin{array}{l}\text { Yellowish brown mottled clayey silt: } 0-305 \mathrm{~cm} \text { with yellowish brown gravel layer at } 17-28 \mathrm{~cm} \text {. Yel- } \\
\text { lowish brown mottled silt: } 305-1059 \mathrm{~cm} \text {. Brown clayey mottled clayey silt: } 1059-1208 \mathrm{~cm} \text {. } \\
\text { Brown mottled silt: } 1230-1256 \mathrm{~cm} \text {. Numerous Mn nodules. }\end{array}$ \\
\hline $\mathrm{E}_{2}$ & $\mathrm{~V} 36 / 12-\mathrm{C} 52$ & $32^{\circ} 21.48^{\prime} \mathrm{N}, 164^{\circ} 11.15^{\prime} \mathrm{E}$ & 1244 & $\begin{array}{l}\text { Yellowish brown to brown mottled clayey silt and lesser amounts of silty clay throughout core. Vol- } \\
\text { canic ash layer at } 934-936 \mathrm{~cm} \text {. }\end{array}$ \\
\hline$E_{2}$ & V36/12-GC53 & $32^{\circ} 24.74^{\prime} \mathrm{N}, 164^{\circ} 08.89^{\prime} \mathrm{E}$ & 289 & Same as above. \\
\hline $\mathrm{B}_{1}^{-}$ & $\mathrm{V} 36 / 12-\mathrm{C} 40$ & $33^{\circ} 39.119^{\prime} \mathrm{N}, 152^{\circ} 13.194^{\prime} \mathrm{E}$ & - & - \\
\hline $\mathbf{B}_{1}$ & $\mathrm{~V} 36 / 12-\mathrm{C} 41$ & $33^{\circ} 21.12^{\prime} \mathrm{N}, 152^{\circ} 03.05^{\prime} \mathrm{E}$ & 1266 & $\begin{array}{l}\text { Laminated olive brown silt: } 0-9 \mathrm{~cm} \text { interbedded yellowish brown to brown silty clay and clayey silt } \\
\text { with brown silt }(590-692 \mathrm{~cm} \text { ): } 9-919 \mathrm{~cm} \text {, brown clay and yellowish brown-brown silty clay: } 919- \\
1178 \mathrm{~cm} \text {. Yellowish brown silt: } 1200-1240 \mathrm{~cm} \text {. Numerous volcanic ash layers. }\end{array}$ \\
\hline $\mathbf{B}_{1}$ & $\mathrm{~V} 36 / 12-\mathrm{GC} 42$ & $33^{\circ} 17.84^{\prime} \mathrm{N}, 152^{\circ} 02.80^{\prime} \mathrm{E}$ & 46 & Same as above. \\
\hline $\mathrm{B}_{1}$ & $\mathrm{~V} 36 / 12-\mathrm{C} 43$ & $33^{\circ} 45.03^{\prime} \mathrm{N}, 151^{\circ} 45.81^{\prime} \mathrm{E}$ & 1247 & $\begin{array}{l}\text { Primarily gray-olive gray silt } 0-49 \mathrm{~cm} \text {. Interbedded gray/olive gray and gray/olive brown silty clay } \\
\text { and clayey silt: } 49-815 \mathrm{~cm} \text {. Gray-olive gray silt at } 605-641,815-1028 \text {, and } 1198-1226 \mathrm{~cm} \text {. Gray- } \\
\text { black clayey silt and silty clay } 1028-1174 \mathrm{~cm} \text {. Numerous volcanic ash layers. }\end{array}$ \\
\hline $\mathrm{B}_{1}$ & $\mathrm{~V} 36 / 12-\mathrm{C} 44$ & $33^{\circ} 23.09^{\prime} \mathrm{N}, 152^{\circ} 02.86^{\prime} \mathrm{E}$ & 1258 & $\begin{array}{l}\text { Interbedded brown, yellowish brown, and grayish brown clayey silt: } 0-604,698-1258 \text {, and } 604- \\
690 \mathrm{~cm} \text {. Brown silt. }\end{array}$ \\
\hline $\mathbf{B}_{1}$ & $\mathrm{~V} 36 / 12-\mathrm{C} 45$ & $33^{\circ} 05.63^{\prime} \mathrm{N}, 152^{\circ} 16.38^{\prime} \mathrm{E}$ & 1264 & $\begin{array}{l}\text { Brown-yellowish brown silt; } 0-9,107-143,445-594 \text {, and } 907-1057 \mathrm{~cm} \text {. Yellowish brown clayey silt: } \\
12-107 \mathrm{~cm} \text {. Interbedded yellowish brown and brown clayey silt and silty clay: } 143-423 \mathrm{~cm} \text {. Yel- } \\
\text { lowish brown silty clay: } 616-714 \mathrm{~cm} \text {. Interbedded brown, yellowish brown, olive brown clayey } \\
\text { silt and silty clay } 736-1228 \mathrm{~cm} \text {. }\end{array}$ \\
\hline
\end{tabular}

Note: $\mathrm{C}=$ piston core, $\mathrm{GC}=$ gravity core. For location of $\mathrm{E}_{2}$ cores, see Figure 2; for location of $\mathrm{B}_{1}$ cores, see Figure 4.

a Compilation of data from Heath (1981).

Table 2. V3612 revised heat-flow summaries for study Areas $\mathrm{E}_{2}$ and $\mathrm{B}_{1}{ }^{\mathrm{a}}{ }^{\mathrm{a}}$

\begin{tabular}{|c|c|c|c|c|c|c|c|}
\hline $\begin{array}{l}\text { DHF } \\
\text { station }\end{array}$ & $\begin{array}{l}\text { Latitude } \\
\text { (N) }\end{array}$ & $\begin{array}{l}\text { Longitude } \\
\text { (S) }\end{array}$ & $\begin{array}{l}\text { Water } \\
\text { depth } \\
\text { (m) }\end{array}$ & $\begin{array}{l}\text { Probe } \\
\text { penetration } \\
(\mathrm{m})\end{array}$ & $\begin{array}{l}\text { Number of } \\
\text { probes }\end{array}$ & $\begin{array}{l}\text { Thermal } \\
\text { gradient } \\
\left(\mathrm{m}^{\circ} \mathrm{C} / \mathrm{m}\right)\end{array}$ & $\begin{array}{c}\text { Heat flow, } Q \\
\left(\mathrm{~mW} / \mathrm{m}^{2}\right)\end{array}$ \\
\hline \multicolumn{8}{|l|}{ Area $B_{1}{ }^{b}$} \\
\hline $47 . \mathrm{V} 36$ & $33^{\circ} 39.6^{\prime}$ & $152^{\circ} 13.0^{\prime}$ & 5978 & 4.0 & 2 & $\geq 69$ & $\geq 57.0^{\mathrm{d}}$ \\
\hline 48-V36 & $33^{\circ} 21.1^{\prime}$ & $152^{\circ} 03.1^{\prime}$ & 6003 & 12.7 & 4 & 56 & 45.6 \\
\hline 49-V36 & $33^{\circ} 45.0^{\prime}$ & $151^{\circ} 45.9^{\prime}$ & 6021 & 12.7 & 3 & 57 & 46.5 \\
\hline $50-\mathrm{V} 36$ & $33^{\circ} 05.6^{\prime}$ & $152^{\circ} 16.4^{\prime}$ & 5888 & 12.7 & 5 & 52 & 42.7 \\
\hline \multicolumn{8}{|l|}{ Area $E_{2}{ }^{c}$} \\
\hline $51-V 36$ & $32^{\circ} 41.0^{\prime}$ & $163^{\circ} 31.5^{\prime}$ & 6162 & 12.7 & 5 & 61 & 52.5 \\
\hline $52-\mathrm{V} 36$ & $32^{\circ} 06.7^{\prime}$ & $164^{\circ} 33.2^{\prime}$ & 6117 & 12.7 & 5 & 61 & 52.4 \\
\hline $53-V 36$ & $32^{\circ} 08.9^{\prime}$ & $163^{\circ} 28.5^{\prime}$ & 6081 & 12.7 & 5 & 66 & 57.0 \\
\hline $54-\mathrm{V} 36$ & $32^{\circ} 24.2^{\prime}$ & $164^{\circ} 16.4^{\prime}$ & 6200 & 11.9 & 5 & 68 & 59.0 \\
\hline $55 \cdot \mathrm{V} 36$ & $32^{\circ} 38.1^{\prime}$ & $164^{\circ} 45.7^{\prime}$ & 6269 & 12.7 & 5 & 90 & $78.0^{\mathrm{e}}$ \\
\hline
\end{tabular}

Note: For locations of $E_{2}$ heat-flow experiments, see Figure 2; for location of $B_{1}$ experiments, see Figure 4.

a From Hayes et al. (1983).

b Conductivity $K=0.818$.

conductivity $K=0.863$.

d Nonlinear.

${ }^{\mathrm{e}}$ Slightly nonlinear.

sequence of bottom-water flow around local bathymetric highs. Thus, by comparing the mapped patterns of anomalous sediment thickness to the bathymetry, the bottom-water circulation patterns can be inferred for each time period defined by discrete reflector intervals.

Many mapped seismic-reflector intervals are defined by reflectors that correspond to cored volcanic ash layers; each of which is an isochron. The ages of these indi- vidual ash horizons were calculated from magnetostratigraphic and biostratigraphic sedimentation rates determined from Sites 576 and 578 (see Site 576 and 578 chapters, this volume).

\section{BATHYMETRY AND ISOPACH METHODOLOGY}

For survey Areas $E_{2}$ (Site 576) and $B_{1}$ (Site 578), the bathymetric and isopach maps of the various reflector 
Table 3. V3612 sonobuoy summaries for study Areas $\mathrm{E}_{2}$ and $\mathrm{B}_{1} \cdot{ }^{\mathrm{a}}$

\begin{tabular}{|c|c|c|c|c|c|c|c|c|c|c|}
\hline Area & Sonobuoy & $\begin{array}{l}\text { Latitude } \\
\text { (N) }\end{array}$ & $\begin{array}{l}\text { Longitude } \\
\text { (E) }\end{array}$ & Layer & Time (s) & $\begin{array}{c}\text { Depth } \\
\text { below } \\
\text { seafloor } \\
(\mathrm{km})\end{array}$ & $\begin{array}{l}\text { Velocity } \\
(\mathrm{km} / \mathrm{sec})\end{array}$ & $\begin{array}{l}\text { Refraction } \\
\text { intercept }\end{array}$ & $\begin{array}{l}\text { Layer } \\
\text { thickness } \\
(\mathrm{km})\end{array}$ & $\begin{array}{c}\text { Layer } \\
\text { thickness } \\
\text { (s) }\end{array}$ \\
\hline \multirow[t]{7}{*}{$\mathrm{B}_{1}$} & $153-V 36$ & $33^{\circ} 51.0^{\prime}$ & $152^{\circ} 15.0^{\prime}$ & 1 & 7.96 & & $1.50^{\mathrm{b}}$ & & 5.970 & \\
\hline & & & & 2 & 8.54 & 0.63 & $2.20^{\mathrm{b}}$ & & 0.63 & 0.58 \\
\hline & & & & 3 & 8.87 & 1.46 & 5.0 & 8.11 & 0.83 & 0.33 \\
\hline & & & & 4 & 9.22 & 2.49 & 5.8 & 8.39 & 1.03 & 0.35 \\
\hline & & & & 5 & 9.67 & 3.99 & 6.8 & 8.72 & 1.50 & 0.45 \\
\hline & & & & 6 & 9.85 & 4.69 & 7.5 & 9.01 & 0.70 & 0.18 \\
\hline & & & & 7 & & & 8.6 & 9.29 & & \\
\hline \multirow[t]{5}{*}{$\mathrm{B}_{1}$} & $156-\mathrm{V} 36$ & $33^{\circ} 20.4^{\prime}$ & $151^{\circ} 51.0^{\prime}$ & 1 & 7.90 & & $1.50^{\mathrm{b}}$ & & 5.925 & \\
\hline & & & & 2 & 8.23 & 0.36 & $2.20^{\mathrm{b}}$ & & 0.36 & 0.33 \\
\hline & & & & 3 & 8.57 & 1.23 & 5.0 & 7.83 & 0.87 & 0.34 \\
\hline & & & & 4 & 8.75 & 1.74 & 5.75 & 8.10 & 0.51 & 0.18 \\
\hline & & & & 5 & & & 6.45 & 8.29 & & \\
\hline \multirow[t]{5}{*}{$\mathrm{B}_{1}$} & $157-\mathrm{V} 36$ & $33^{\circ} 7.8^{\prime}$ & $151^{\circ} 43.2^{\prime}$ & 1 & 7.939 & & $1.50^{\mathrm{b}}$ & & 5.954 & \\
\hline & & & & 2 & 8.288 & 0.36 & 2.08 & & 0.36 & 0.35 \\
\hline & & & & 3 & 8.55 & 0.82 & $3.50^{\mathrm{b}}$ & & 0.46 & 0.26 \\
\hline & & & & 4 & 9.03 & 2.19 & 5.75 & 8.20 & 1.37 & 0.48 \\
\hline & & & & 5 & & & 6.45 & 8.49 & & \\
\hline \multirow[t]{5}{*}{$\mathrm{E}_{2}$} & $158-\mathrm{V} 36$ & $32^{\circ} 41.4^{\prime}$ & $164^{\circ} 25.2^{\prime}$ & 1 & 8.260 & & $1.50^{\mathrm{b}}$ & & 6.195 & \\
\hline & & & & 2 & 8.65 & 0.43 & $2.20^{\mathrm{b}}$ & & 0.43 & 0.39 \\
\hline & & & & 3 & 9.23 & 2.18 & 6.0 & 8.36 & 1.75 & 0.58 \\
\hline & & & & 4 & 9.72 & 3.94 & 7.25 & 8.78 & 1.76 & 0.49 \\
\hline & & & & 5 & & & 8.25 & 9.13 & & \\
\hline \multirow[t]{6}{*}{$\mathrm{E}_{2}$} & $159-\mathrm{V} 36$ & $32^{\circ} 5.4^{\prime}$ & $164^{\circ} 9.0^{\prime}$ & 1 & 8.013 & & $1.50^{\mathrm{b}}$ & & 6.01 & \\
\hline & & & & 2 & 8.41 & 0.43 & 2.17 & & 0.43 & 0.40 \\
\hline & & & & 3 & 8.55 & 0.66 & $3.50^{\mathrm{b}}$ & & 0.23 & 0.14 \\
\hline & & & & 4 & 8.81 & 1.37 & 5.30 & 8.15 & 0.71 & 0.26 \\
\hline & & & & 5 & 9.19 & 2.55 & 6.15 & 8.39 & 1.18 & 0.38 \\
\hline & & & & 6 & & & 6.80 & 8.66 & & \\
\hline \multirow[t]{6}{*}{$\mathrm{E}_{2}$} & $160-\mathrm{V} 36$ & $32^{\circ} 4.2^{\prime}$ & $163^{\circ} 53.4^{\prime}$ & 1 & 8.055 & & $1.50^{\mathrm{b}}$ & & 6.042 & \\
\hline & & & & 2 & 8.62 & 0.70 & $2.50^{\mathrm{b}}$ & & 0.70 & 0.56 \\
\hline & & & & 3 & 8.73 & 0.97 & 4.80 & 8.13 & 0.27 & 0.11 \\
\hline & & & & 4 & 9.19 & 2.30 & 5.80 & 8.35 & 1.33 & 0.46 \\
\hline & & & & 5 & 9.61 & 3.67 & 6.60 & 8.66 & 1.37 & 0.42 \\
\hline & & & & 6 & & & 8.15 & 9.11 & & \\
\hline \multirow[t]{5}{*}{$\mathrm{E}_{2}$} & $161-V 36$ & $32^{\circ} 20.4^{\prime}$ & $164^{\circ} 58.8^{\prime}$ & 1 & 8.173 & & $1.50^{\mathrm{b}}$ & & 6.130 & \\
\hline & & & & 2 & 8.66 & 0.40 & 1.61 & & 0.40 & 0.50 \\
\hline & & & & 3 & 8.67 & 0.407 & $2.50^{\mathrm{b}}$ & & 0.007 & 0.003 \\
\hline & & & & 4 & 9.12 & 1.737 & 5.85 & 8.38 & 1.33 & 0.45 \\
\hline & & & & 5 & & & 6.30 & 8.59 & & \\
\hline \multirow[t]{7}{*}{$\mathrm{E}_{2}$} & $162-\mathrm{V} 36$ & $32^{\circ} 19.8^{\prime}$ & $164^{\circ} 35.4^{\prime}$ & 1 & 8.091 & & $1.50^{\mathrm{b}}$ & & & \\
\hline & & & & 2 & 8.55 & 0.63 & 2.70 & & 0.63 & 0.466 \\
\hline & & & & 3 & 8.63 & 0.73 & $3.00^{\mathrm{b}}$ & & 0.10 & 0.07 \\
\hline & & & & 4 & 8.80 & 1.08 & 4.050 & 7.91 & 0.35 & 0.17 \\
\hline & & & & 5 & 9.16 & 1.99 & 5.050 & 8.28 & 0.91 & 0.36 \\
\hline & & & & 6 & 9.59 & 3.22 & 5.800 & 8.59 & 1.23 & 0.43 \\
\hline & & & & 7 & & & 6.250 & 8.84 & & \\
\hline \multirow[t]{7}{*}{$\mathrm{E}_{2}$} & $163-\mathrm{V} 36$ & $32^{\circ} 27.0^{\prime}$ & $163^{\circ} 53.4^{\prime}$ & 1 & 8.082 & & $1.50^{b}$ & & 6.061 & \\
\hline & & & & 2 & 8.55 & 0.42 & 1.78 & & 0.42 & 0.472 \\
\hline & & & & 3 & 8.57 & 0.44 & $2.50^{\mathrm{b}}$ & & 0.02 & 0.016 \\
\hline & & & & 4 & 8.90 & 1.29 & 5.20 & 8.20 & 0.85 & 0.33 \\
\hline & & & & 5 & 9.11 & 1.90 & 5.85 & 8.43 & 0.61 & 0.21 \\
\hline & & & & 6 & 9.57 & 3.50 & 6.90 & 8.69 & 1.60 & 0.46 \\
\hline & & & & 7 & & & 7.40 & 8.92 & & \\
\hline
\end{tabular}

Note: For location of $E_{2}$ sonobuoys, see Figure 2; for location of $B_{1}$ sonobuoys, see Figure 4.

${ }^{a}$ From Hayes et al. (1983).

b ' $D$ velocities are assumed.

intervals are based primarily on $3.5-\mathrm{kHz}$ echogram data collected from Vema Cruise 3612. The seafloor and distinctive sub-bottom reflectors were digitized at 1-min. intervals from the original $3.5-\mathrm{kHz}$ echograms. Additional data were digitized from the various cruises shown in Figures 2 and 4 . For the bathymetric maps, the digi- tized two-way travel times were converted to corrected meters by using Carter's correction tables (Carter, 1980). For isopach maps, the digitized two-way travel times to individual reflectors were converted to meters below seafloor (bsf) by using an assumed sediment velocity of $1550 \mathrm{~m} / \mathrm{s}$. This velocity is consistent both with DSDP/ 

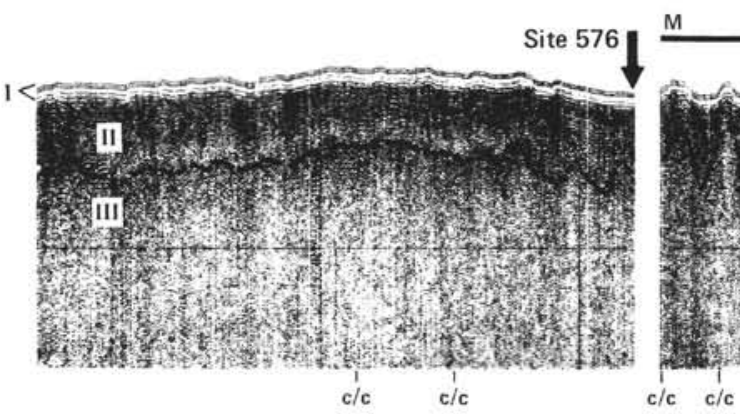

c/c

$\mathrm{c} / \mathrm{c}$

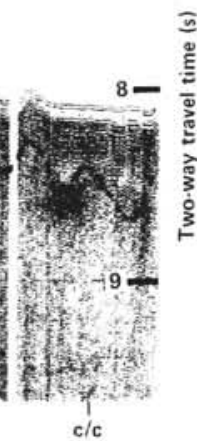

Figure 3. Single-channel, $\sim 100-\mathrm{Hz}$ seismic reflection Profile $\mathrm{Y}-\mathrm{Z}$ (location shown in Fig. 2). The locations of the 3.5-kHz echogram Profile M-N (displayed in Fig. 6) and DSDP Site 576 are shown. $\mathrm{C} / \mathrm{C}=$ change course. Vertical exaggeration is 50:1.

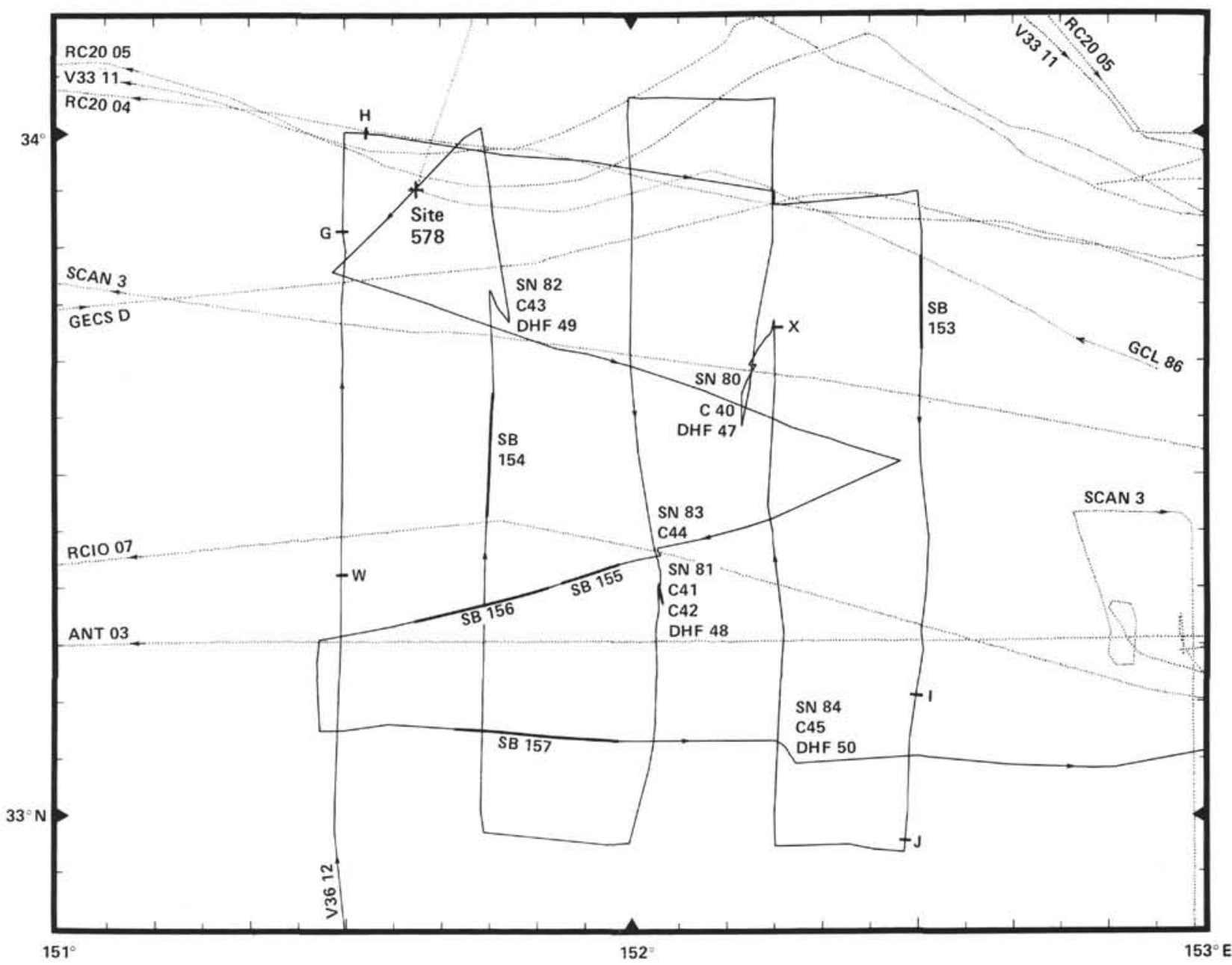

Figure 4. Cruise track lines and station-location index map for study Area $B_{1}$ (after Damuth et al., 1980 and Hayes et al., 1983); track identification as follows: $\mathrm{V}=$ Vema, $\mathrm{RC}=$ Robert $\mathrm{D}$. Conrad, $\mathrm{GCL}=$ Glomar Challenger, $\mathrm{ANT}=$ Antipode cruise, $\mathrm{SCAN}=A R G O$, GEOS $=$ Geosecs cruise on Melville. Sonobuoy (SB) and ship station $(\mathrm{SN})$ locations are shown $(\mathrm{C}=$ core, $\mathrm{DHF}=\mathrm{digital}$ heat-flow measurement). The $\sim 100-\mathrm{Hz}$ seismic reflection Profile W-X is shown in Figure 5; 3.5-kHz echogram Profiles G-H and I-J are shown in Figure 11. 

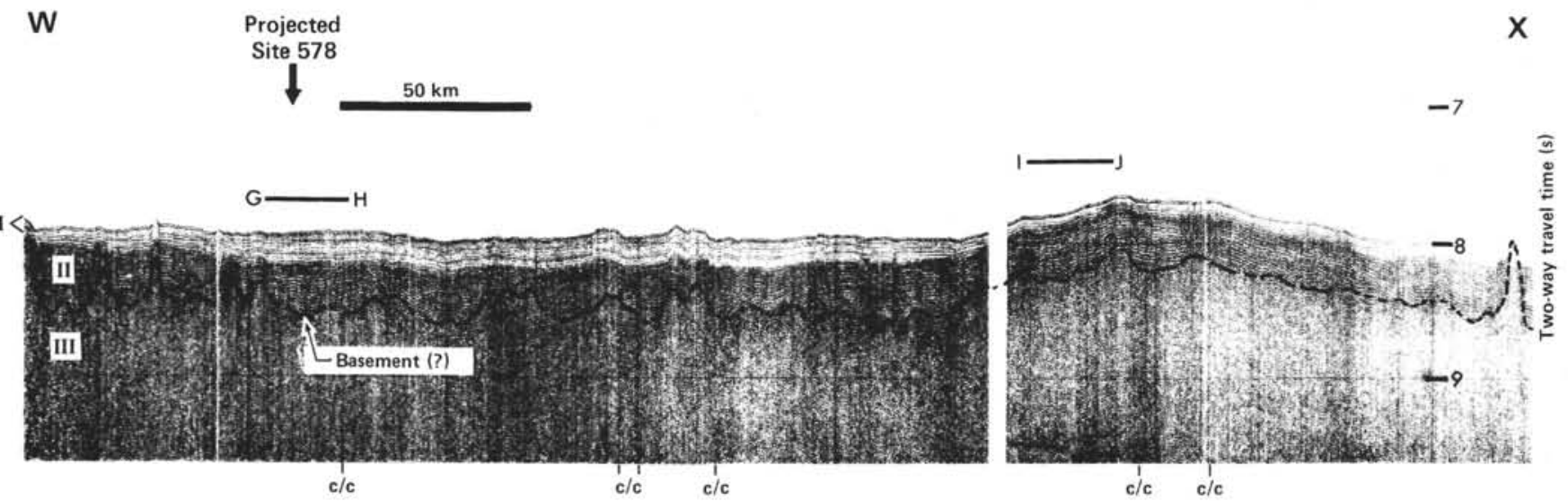

Figure 5. Single-channel $\sim 100-\mathrm{Hz}$ seismic reflection profile W-X (from Damuth et al., 1980 and Hayes et al., 1983); for location of Profile W-X, see Figure 4. Location of 3.5-kHz echogram Profiles G-H and I-J are shown, as well as the projected location of DSDP Site 578. Note the dramatic northward thickening of the relatively transparent upper section from $\mathrm{W}$ to $\mathrm{H}$ and both thickening and thinning in the region of Profile $\mathrm{I}-$ $\mathrm{J}$. $\mathrm{C} / \mathrm{C}=$ change course. Vertical exaggeration is $50: 1$.

IPOD Leg 86 shipboard velocity profiles (see site chapters, this volume) and with velocity studies of piston cores and $3.5-\mathrm{kHz}$ hydrophone-pinger studies in these areas (Flood, pers. comm., 1983; Hayes et al., 1983). We estimate the digitization error to be $\sim 1 \mathrm{~m}$. Depth and sediment thickness crossover errors at intersecting tracks were calculated in order to assess the internal consistency of the data. Crossover errors may be caused by problems in navigation, reflector misidentification, and instrumentation errors. The average crossover error of Reflector $R_{1}$ (seafloor) for the V3612 survey at study Area $E_{2}$ is $\sim 3 \mathrm{~m}$ and is $\sim 6 \mathrm{~m}$ at study Area $\mathrm{B}_{1}$. Average crossover errors for other cruises with respect to the V3612 surveys are greater, as much as $\sim 30 \mathrm{~m}$ for Glomar Challenger Leg 86. At study Areas $\mathrm{E}_{2}$ and $\mathrm{B}_{1}$, digitized reflectors from the V3612 survey are internally consistent to within $1 \mathrm{~m}$ for shallow reflectors and $2 \mathrm{~m}$ for deep reflectors (e.g., $R_{5}$ ). For other cruises, the errors with respect to the V3612 survey are greater (up to $10 \mathrm{~m}$ ). For all reflectors, selected tracks of cruises other than V3612 were adjusted by adding constant corrections to the recorded depths.

\section{STUDY AREA E $\mathbf{E}_{\mathbf{2}}$-SITE 576}

\section{Seismic Section}

At Area $\mathrm{E}_{2}, 3.5-\mathrm{kHz}$ echograms reveal that two seismic subunits (Fig. 6) comprise the seismic Unit 1 defined by $100-\mathrm{Hz}$ seismic profiles (Fig. 3). The uppermost subunit, Reflector $\mathbf{R}_{1}$ (seafloor) to Reflector $\mathbf{R}_{3}$, consists of continuous, multiple, sharp and parallel reflectors. This subunit corresponds to a section of brown clay with a few volcanic ash layers. A few small areas with relatively steep gradients return hyperbolic reflections (Fig. 6). Two strong, continuous reflectors, $R_{2}$ and $R_{3}$, occur at $\sim 12 \mathrm{~m}$ bsf and $\sim 22 \mathrm{~m}$ bsf, respectively. Reflector $R_{2}$ corresponds to an $\sim 1.295$ m.y. old volcanic ash layer cored at $12.18 \mathrm{~m}$ bsf in Hole 576. Reflector $\mathrm{R}_{3}$ does not correspond to any observed major lithologic change in either Hole 576 or Hole 576B. However, at the expected depth of the reflector, a large void occurs in Core 576-3 and highly disturbed intervals occur in Sections 4 and 5 of Core 576B-3. Thus, Reflector $\mathrm{R}_{3}$ could represent a lithologic boundary (a volcanic ash layer?) that was unsampled. The reflector might also be caused by the sharp decrease in porosity in the DSDP cores at about the depth of the reflector (Flood, pers. comm., 1983). The interpolated age of such a boundary is $\sim 7.2 \mathrm{~m}$.y. Both Reflectors $R_{2}$ and $R_{3}$ are regional in extent and can be traced at least $190 \mathrm{~km}$ to the southeast of Site 576 . Reflector $\mathrm{R}_{3}$ can be traced $\sim 380 \mathrm{~km}$ westward to the eastern flank of the Shatsky Rise, where it disappears. Although Reflector $R_{2}$ is discontinuous on the eastern flank of the Shatsky Rise, its distinct character is very similar to that of Reflector 1-e observed on the Shatsky Rise at Site 577. Volcanic ash layers cored at the level of Reflectors 1-e and $R_{2}$ at both sites have essentially identical ages. A weaker, but continuous, sharp reflector occurs between Reflectors 2 and 3 (Fig. 6) at $\sim 16 \mathrm{~m}$ bsf. This reflector probably corresponds to a series of thin, closely spaced ash layers cored in Hole 576B that have ages ranging from 1.79 m.y. to $\sim 2.37$ m.y.

Although the reflectors in the upper subunit are generally parallel, detailed examination of the echograms (e.g., Fig. 6) reveals local variations in the subunit thickness near abyssal hills. The character of the reflectors in the areas of the thickened sections (commonly at the base of steep slopes) suggests that they represent sediment-slide deposits (e.g., areas A and B in Fig. 6). In contrast, a gradual thinning of both intervals $R_{1}-R_{2}$ and $R_{2}-R_{3}$ occurs over many abyssal hills (e.g., Area $C$ on Fig. 6). Very localized thinning is also observed at the base of steep slopes and is probably caused by accelerated bottom-water flow in some areas (e.g., Area D, Fig. 6). In other areas (possibly part of Area E, Fig. 6) the thinning may represent slide scars. In Figure 6, both thinning and thickening appear to be more prevalent in the interval $R_{1}-R_{2}(0-1.3$ m.y. ago) than in the interval $R_{2}-R_{3}$ (1.3-7.2 m.y. ago).

The lower subunit of seismic Unit 1 is primarily a thick transparent section with discontinuous, sharp to slightly prolonged reflectors (Fig. 6). The transparent section corresponds to brown clay. Reflector $\mathbf{R}_{4}$ (the prevalent discontinuous reflector) occurs about two-thirds of 

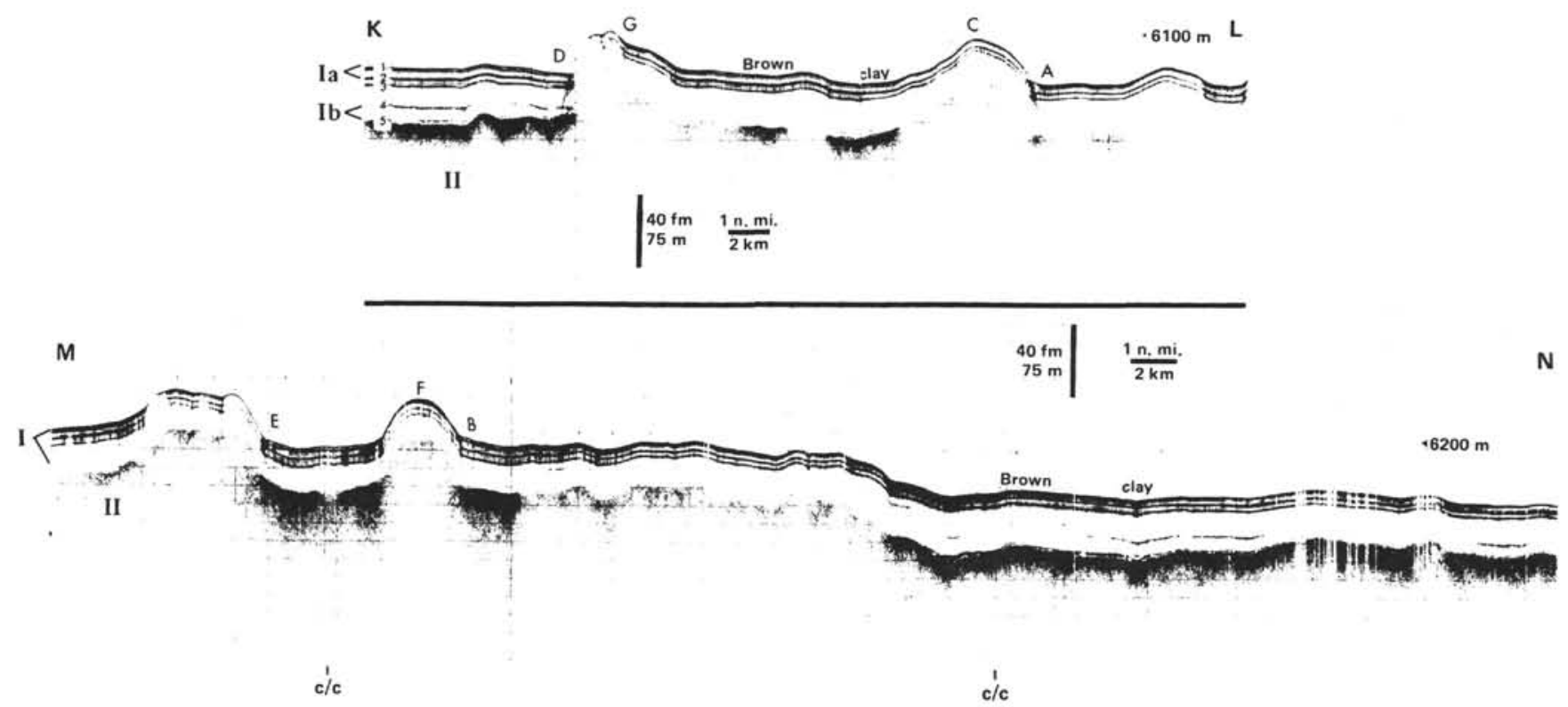

Figure 6. High-resolution seismic Profiles (3.5-kHz echograms) $\mathrm{K}-\mathrm{L}$ and $\mathrm{M}-\mathrm{N}$ in study Area $\mathrm{E}_{2}$ (locations in Fig. 2). Digitized reflectors are numbered and $R_{2}$ is $1.295 \mathrm{~m}$.y. old, $R_{3}=\sim 7.2 \mathrm{~m}$.y. old, $R_{4}=\sim 25 \mathrm{~m}$.y. old, and $R_{5}$ is $\sim 70 \mathrm{~m}$.y. old. Areas $A$ and $B$ show localized, near-surface sediment slide deposits; Area $C$ exhibits gradual thinning of reflector intervals on the slope and also illustrates the diffuse character of $R_{5}$ on relative highs; Area D shows gradual thinning at the margin of the trough caused by accelerated bottom-water flow; Area $\mathrm{E}$ exhibits thinning and thickening caused by buried sediment slide scar and deposit; and Areas F and $\mathrm{G}$ illustrate the diffuse character of $\mathrm{R}_{5}$ on highs. $\mathrm{C} / \mathrm{C}=$ course change. Profile K-L: vertical exaggeration is 46:1; Profile M-N: vertical exaggeration is 42:1.

the way down the lower subunit and at Site 576 its age is assumed to be $\sim 25$ m.y. It is possible that $R_{4}$ does not represent a single lithologic unit. Reflector $\mathbf{R}_{4}$ does not correlate with any observed lithologic change in the Site 576 cores; the cause of the discontinuous reflectors thus remains a puzzle.

Seismic Unit II consists of several different $3.5-\mathrm{kHz}$ echo types. On abyssal hills these echoes are generally diffuse, weak, and prolonged (e.g., Areas C, F, and G in Fig. 6). A few weak hyperbolic reflections are observed along the steep slopes of abyssal hills (e.g., Area G in Fig. 6). In contrast, areas of smoother slopes and lower gradients between abyssal hills return strong, sharp to prolonged echoes. In some of these areas, multiple strong echoes can be discerned, and at Site 576 these appear to onlap the more diffuse echoes returned from abyssal hills. The relatively smooth, strong echoes probably correspond to the Campanian to early Maestrichtian ( $\sim 70$ m.y. ago) carbonate turbidites interbedded with brown clay cored at Site 576. The weak diffuse echoes on the abyssal hills have several possible sources: (1) carbonate layers equivalent to those cored at Site 576, (2) a discontinuous chert layer at $\sim 55 \mathrm{~m}$ bsf that was not cored at Site 576 , and (3) a single, generally continuous chert layer, but with considerably more relief than the seafloor (note that the chert was cored at $76 \mathrm{~m}$ bsf whereas the diffuse echo commonly occurs elsewhere at $55 \mathrm{~m} \mathrm{bsf}$ ). Reflector 5 is the first prolonged echo encountered at the base of the transparent seismic Unit I and defines "acoustic basement" on $3.5-\mathrm{kHz}$ echograms.

\section{Bathymetry (Reflector $\mathbf{R}_{1}$ )}

The seafloor at Area $E_{2}$ has a regional slope from the southwest $(6017 \mathrm{~m})$ to the northeast $(6267 \mathrm{~m}$, Fig. 7).
Small ridges and isolated abyssal hills occur throughout the area; the shoalest abyssal hill reaches a depth of $5865 \mathrm{~m}$ and has relief of $305 \mathrm{~m}$. The seafloor is characterized by a series of lineated ridges that trend northwest to southeast $\left(\sim 130^{\circ}\right)$. This trend is parallel to observed seafloor-spreading magnetic lineations in Area $\mathrm{E}_{2}$ and strongly suggests that the ridges are related to mid-ocean ridge rifting phenomena (e.g., fault blocks, scarps, and volcanic ridges).

The study area can be divided into six bathymetric provinces (Fig. 8, Table 4): a northeast province with very subdued bathymetry (A), a southeast province with lineated and relatively steep ridges and valleys (B), a northwest-trending central valley and ridge $(C)$, a province southwest of the central valley with subdued relief (D), and provinces of abyssal hills along the southern margin of D and in the northwestern corner of the site survey (Provinces E and F, respectively). Computer-generated, perspective drawings of the seafloor at Site $\mathrm{E}_{2}$ (Fig. 9) provide a better "sense" of the very low relief within the study area.

\section{Intervals $\mathbf{R}_{\mathbf{1}}-\mathbf{R}_{\mathbf{2}}$ and $\mathbf{R}_{\mathbf{2}}-\mathbf{R}_{\mathbf{3}}$}

The regional and local variations in the $R_{1}-R_{2}$ interval thicknesses are similar to those of the $R_{2}-R_{3}$ interval (Figs. 10A and 10B). The thickness of interval $R_{1}-R_{2}$ is generally $12 \mathrm{~m}$ (sedimentation rate $=9.2 \mathrm{~mm} / 1000$ yr.) in the central and western areas but decreases to a minimum of $3 \mathrm{~m}(2.32 \mathrm{~mm} / 1000 \mathrm{yr}$.) in the northeast. The thickness of interval $R_{2}-R_{3}$ varies from 10 to $11 \mathrm{~m}$ (1.79 $\mathrm{mm} / 1000 \mathrm{yr}$. $)$ in the southwest to $\sim 4 \mathrm{~m}(0.68 \mathrm{~mm} / 1000$ yr.) in the northeast. The thinning to the northeast is also observed in the other reflector intervals. Local variations in these interval thicknesses generally range from 1 




Figure 7. Bathymetry of study Area $\mathrm{E}_{2}$. Depths are in corrected meters, using the correction tables of Carter (1980). Primary contour interval is $10 \mathrm{~m}$. 




Figure 8. Bathymetric provinces $(\mathrm{A}-\mathrm{F})$ in study Area $\mathrm{E}_{2}$. Provinces are defined by characteristic bathymetric features. 
Table 4. Characteristics of bathymetric features in provinces of study Area $\mathrm{E}_{2}{ }^{\mathrm{a}}$.

\begin{tabular}{|c|c|c|c|c|c|c|}
\hline \multirow[b]{2}{*}{ Province } & \multirow{2}{*}{$\begin{array}{l}\text { Depth range } \\
\text { (m) }\end{array}$} & \multicolumn{2}{|c|}{ Relief (m) } & \multicolumn{2}{|c|}{ Slope $\left({ }^{\circ}\right)$} & \multirow{2}{*}{$\begin{array}{l}\text { Wavelength } \\
(\mathrm{km})\end{array}$} \\
\hline & & General & Maximum & General range & Maximum & \\
\hline A & $6200-6267$ & & 38 & $0.1-0.5$ & $\sim 1.5$ & $3-9$ \\
\hline B & $6010-6220$ & & 160 & $0.5-3$ & 8 & $\begin{array}{l}\text { Common: } 4-5 \\
\text { Maximum: } 9-10\end{array}$ \\
\hline $\mathrm{C}$ & $-6150-6200$ & $30-40$ & 58 & $<3$ & 6 & $5-11$ \\
\hline D & & $<50$ & $<80$ & $0.1-1.0$ & $2-3$ & $7-23$ \\
\hline \multicolumn{7}{|l|}{ E } \\
\hline Western & $6035-6073$ & & 38 & 4 & & \\
\hline Eastern & $6043-6140$ & 30 & 42 & $0.5-1.5$ & 3 & \\
\hline F & $5863-6170$ & $17-44$ & 307 & $0.5-2$ & 4.5 & \\
\hline
\end{tabular}

${ }^{a}$ Based on Figure 7.
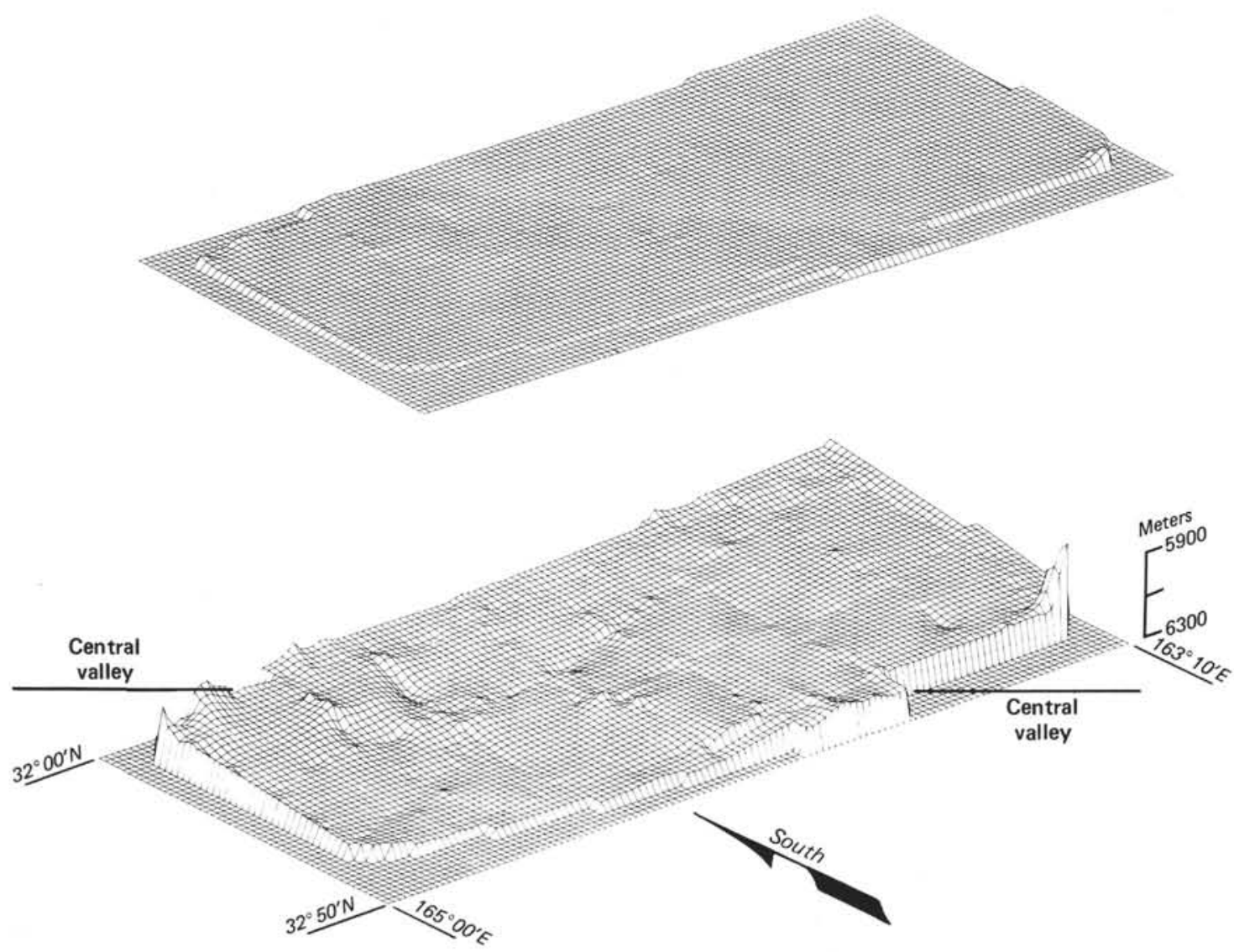

Figure 9. Three-dimensional south-looking view of the seafloor at study Area $\mathrm{E}_{2}$. Upper plot with smaller vertical exaggeration (10:1) has same coordinates as lower plot (vertical exaggeration is 50:1). Note northwest-trending central valley and the abyssal hills along the borders of $\mathrm{E}_{2}$.

to $4 \mathrm{~m}$ and are commonly $<2 \mathrm{~m}$. However, in moats the $R_{1}-R_{2}$ thicknesses decrease as much as $6 \mathrm{~m}$ and the $R_{2-}$ $R_{3}$ thickness may vary by as much as $10 \mathrm{~m}$ (Province $\mathrm{B}$ ).

Variations in sedimentation rate are related to the direction, steepness, and extent of seafloor slopes. If anomalous sections were primarily the result of unidirectional bottom-water flow, one would expect that one slope direction would consistently have a thinner sediment section while the opposing slope would be consistently thicker. Because anomalously thick and thin zones can be observed in any hill, slope, or trough setting (Table 5) factors other than regional bottom-water flow (e.g., mass wasting) must contribute to anomalous sedimentation. However, within regions characterized by relatively steep seafloor slopes, it is clear that anomalously thin sedimentary sections occur preferentially: (1) on northeast facing slopes (e.g., eastern portion of Province F; southwest portion of Province D) and (2) along the margins of small basins and troughs. These relationships strongly suggest that bottom-water flow does play an im- 


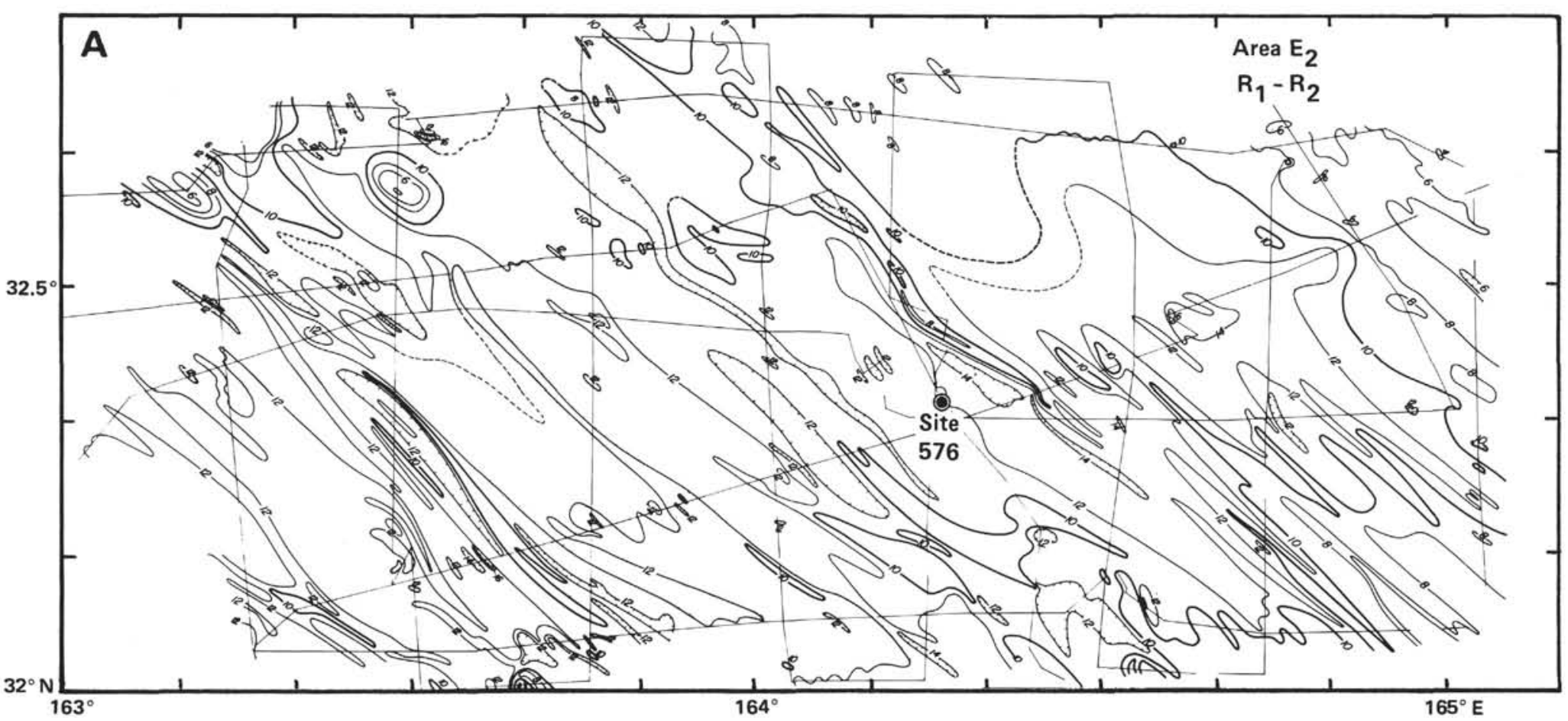




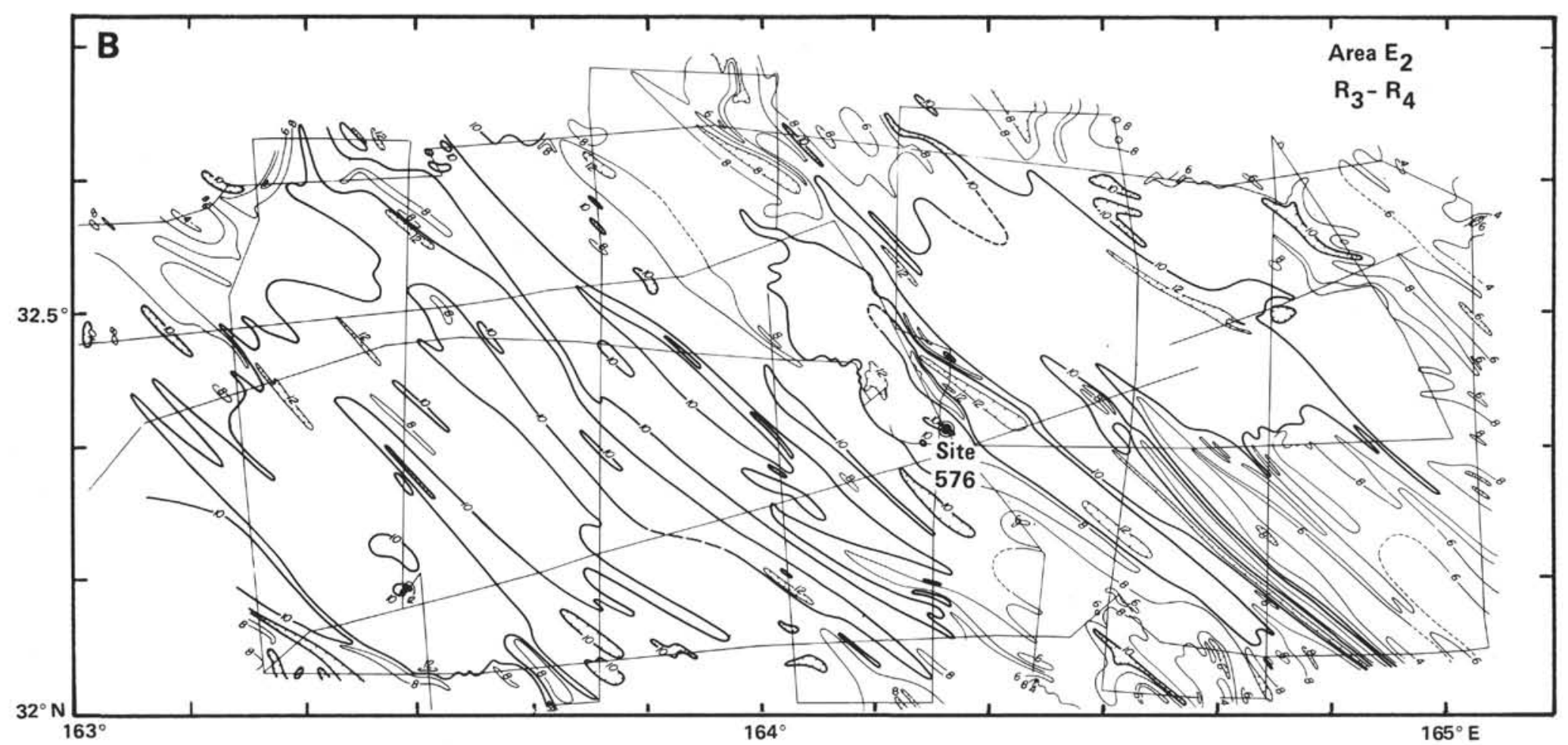

Figure 10. Isopach maps for the various 3.5-kHz seismic reflector intervals in study Area $E_{2}$; assumed interval velocity $=1550 \mathrm{~m} / \mathrm{s}$. Figure $10 \mathrm{~A}$ : interval $R_{1}-R_{2}(0-1.295$ m.y.), Figure 10B: interval $R_{2}-R_{3}(1.295-7.2 \mathrm{~m} . y$.$) , Figure 10C: R_{3}-R_{5}(7.2-\sim 70 \mathrm{~m} . y$.$) . Contour interval is 2 \mathrm{~m}$ for Figures $10 \mathrm{~A}$ and $10 \mathrm{~B}$ and the primary contour interval for Figure $10 \mathrm{C}$ is $4 \mathrm{~m}$. 


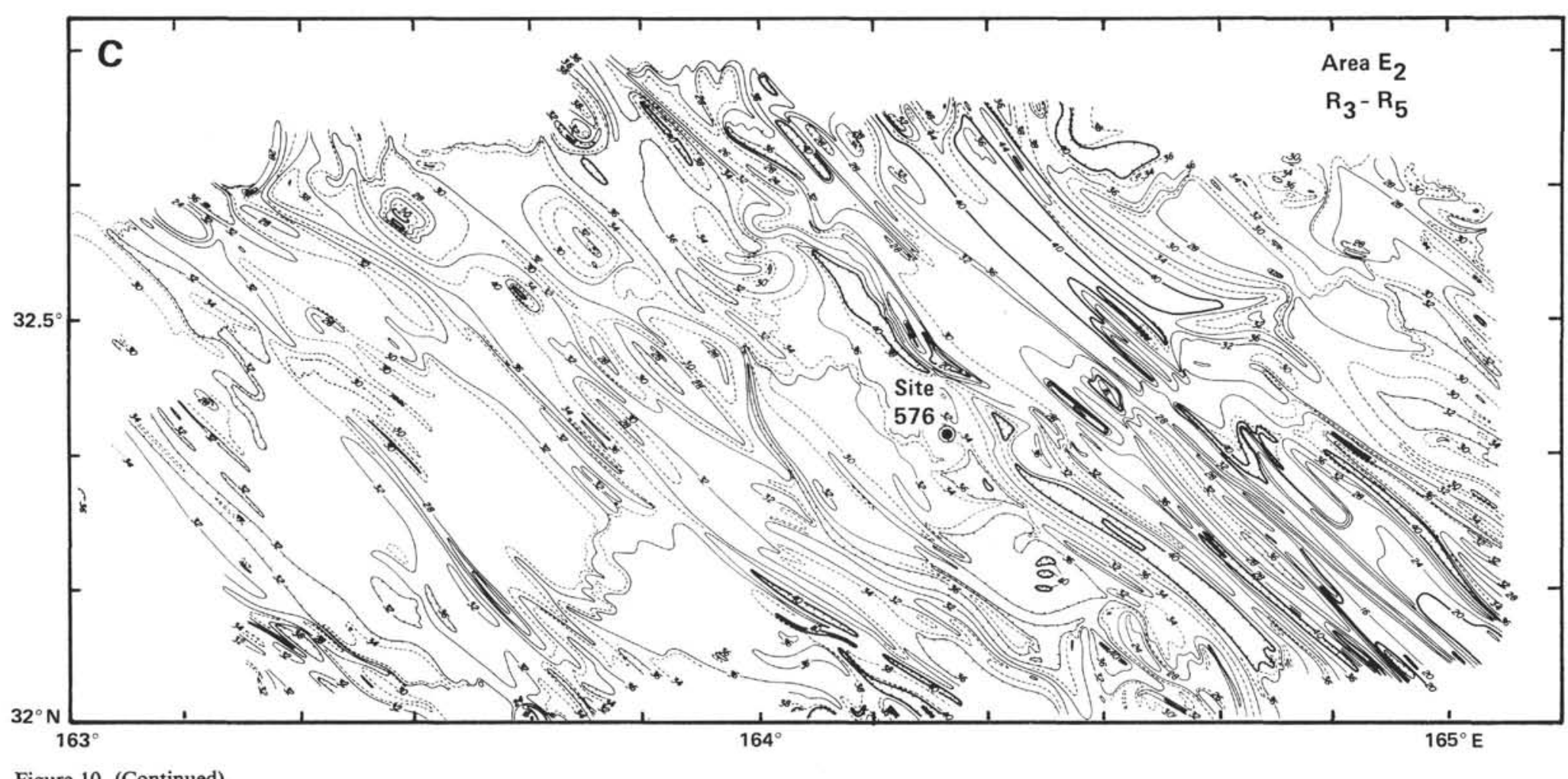

Figure 10. (Continued). 
Table 5. Nature of the seafloor slope in areas with anomalous sediment accumulation rates. ${ }^{\mathrm{a}}$

\begin{tabular}{|c|c|c|c|c|c|c|}
\hline $\begin{array}{l}\text { Reflector } \\
\text { interval }\end{array}$ & $\begin{array}{l}\text { Seafloor } \\
\text { slopes to } \\
\text { NE }(\%)\end{array}$ & $\begin{array}{l}\text { Seafloor } \\
\text { slopes to } \\
\text { SW (\%) }\end{array}$ & $\begin{array}{c}\text { Centered on } \\
\text { seafloor low } \\
(\%)\end{array}$ & $\begin{array}{l}\text { Centered on } \\
\text { seafloor high } \\
(\%)\end{array}$ & $\begin{array}{c}\text { At base of } \\
\text { NE slope } \\
(\%)\end{array}$ & $\begin{array}{c}\text { At base of } \\
\text { SW slope } \\
(\%)\end{array}$ \\
\hline \multicolumn{7}{|c|}{ Anomalously thin zones } \\
\hline$R_{1}-R_{2}$ & $\stackrel{55}{(n=47)}$ & $\begin{array}{c}23 \\
(n=20)\end{array}$ & $\begin{array}{c}22 \\
(n=19)\end{array}$ & & & \\
\hline $\mathrm{R}_{2}-\mathrm{R}_{3}$ & $\begin{array}{c}38 \\
(n=31)\end{array}$ & $\begin{array}{c}17 \\
(n=14)\end{array}$ & $\begin{array}{c}5 \\
(n=4)\end{array}$ & $\begin{array}{c}28 \\
(n=23)\end{array}$ & $\stackrel{\stackrel{7}{=}(n)}{=}$ & $\begin{array}{c}5 \\
(n=4)\end{array}$ \\
\hline$R_{3}-R_{5}$ & $(n=40)$ & $\begin{array}{c}16 \\
(n=15)\end{array}$ & $(n=4$, moat $)$ & $(n=28)$ & $(n=7)$ & $(n \stackrel{2}{=} 2)$ \\
\hline \multicolumn{7}{|c|}{ Anomalously thick zones } \\
\hline$R_{1}-R_{2}$ & $\begin{array}{c}40 \\
(n=36)\end{array}$ & $\stackrel{12}{12}=11)$ & $\begin{array}{c}25 \\
(n=22)\end{array}$ & $(n \stackrel{7}{=} 6)$ & $(n \stackrel{6}{=} 5)$ & $\begin{array}{c}10 \\
(n=9)\end{array}$ \\
\hline $\mathbf{R}_{2}-\mathbf{R}_{3}$ & $\begin{array}{c}24 \\
(n=25)\end{array}$ & $\begin{array}{c}10 \\
(n=10)\end{array}$ & $\begin{array}{c}30 \\
(n=31)\end{array}$ & $(n=7)$ & $(n=12)$ & $\begin{array}{c}17 \\
(n=17)\end{array}$ \\
\hline$R_{3}-R_{5}$ & $\begin{array}{c}30 \\
(n=37)\end{array}$ & $\begin{array}{c}9 \\
(n=11)\end{array}$ & $\begin{array}{c}27 \\
(n=34)\end{array}$ & $(n=6)$ & $\begin{array}{c}19 \\
(n=24)\end{array}$ & $\begin{array}{c}10 \\
(n=13)\end{array}$ \\
\hline
\end{tabular}

Note: $n=$ number of observations, $\%=(n / \Sigma n) \times 100$ for each horizontal series.

Based on comparison of Figure 10 with Figure ?

portant role in effecting the ultimate sediment disposition. According to our simple model, bottom-water flow either to the southwest or southeast is indicated.

Two "basins" at $\sim 32.6^{\circ} \mathrm{N}, 163.2^{\circ} \mathrm{E}$ and at $32.6^{\circ} \mathrm{N}$, $163.5^{\circ} \mathrm{E}$ have anomalously thin sediment sections and may actually be moats around seamounts that were undetected by the survey.

\section{Interval $\mathbf{R}_{\mathbf{3}}-\mathbf{R}_{\mathbf{5}}$}

Interval $R_{3}-R_{5}$ is the integral of intervals $R_{3}-R_{4}$ and $R_{4}-R_{5}$. The uncertainty involved in correlating $R_{4}$ from one occurrence to another precludes detailed analysis of regional sedimentation rate variations within interval $R_{3}-$ $\mathbf{R}_{\mathbf{5}}$. Reflectors 3 and 5 occur throughout most of the site survey and therefore show a spatially complete picture of the variations in sedimentation rate during $R_{3}-R_{5}$ times (Fig. 10C). The regional interval thickness decreases northeastward from $\sim 32 \mathrm{~m}$ in the southwest to $\sim 28 \mathrm{~m}$ in the northeast. Province $\mathrm{C}$ has an average thickness of $38-39 \mathrm{~m}$ in the central valley.

The local variations in thickness of $R_{3}-R_{5}$ are similar to the upper intervals (Table 5). Both anomalously thick and thin zones occur primarily on northeast-sloping seafloor. Anomalously thin zones are also centered on bathymetric highs and a few occur along the margins of troughs. Thick zones are also centered on bathymetric lows, margins of troughs, and bathymetric highs. The relatively high proportion of $R_{3}-R_{4}$ thick zones at the margins of troughs (compared to $R_{1}-R_{2}$ and $R_{2}-R_{3}$ ) may suggest a greater debris flow/turbidity flow or less bottom-water influence on the sedimentation in $R_{3}-R_{4}$ time ( 25-7 m.y. ago).

Like the upper intervals, the relationships of thin zone/ northeast slope, thick zone/southwest slope are observed in interval $R_{3}-R_{5}$ in regions of steep seafloor gradients (e.g., the ridges in Province B); these relationships also suggest bottom-water flow to the southeast or southwest. However, $R_{4}-R_{5}$ thickness minima occur along the northeast margins of troughs and therefore suggest opposite flow direction. Because of the small number of observations of $R_{4}-R_{5}$, the resolution of this apparent discrepancy is unclear. The $\mathbf{R}_{\mathbf{4}}-\mathrm{R}_{5}$ observations may simply record local flow directions.

\section{STUDY AREA B $B_{1}$-SITE 578}

\section{Seismic Section}

In the southern part of study Area $B_{1}$, there are four sets of strong, continuous, and generally parallel 3.5$\mathrm{kHz}$ reflectors (Fig. 11), all within the $100-\mathrm{Hz}$ seismic Unit I (Fig. 5). The uppermost group includes the seafloor $\left(R_{1}\right)$. Because the uppermost reflector of the second group is not continuous throughout Area $B_{1}$, the lower, stronger reflector of the second group was defined as Reflector $R_{2}$. The uppermost reflector of the third group is defined as $R_{3}$ and commonly is weaker than the underlying reflectors in the third group. The uppermost reflector of the fourth group (composed of a series of strong, continuous reflectors) is defined as $\mathbf{R}_{\mathbf{4}}$; the weak, somewhat discontinuous reflector at the base of the fourth group is defined as $R_{5}$ (the fourth reflector below $R_{4}$ ). Because this reflector merges with the overlying reflectors in some areas and fades out in a few areas, the intervals involving $R_{5}$ are not as well defined as the overlying intervals. Reflector $R_{6}$ is the relatively strong, continuous reflector that is separated from $R_{5}$ by a thick semitransparent section.

Within Area $\mathrm{B}_{1}$ all reflectors become progressively deeper and more separated to the north, illustrating pronounced increases in sedimentation rates (Fig. 11). Thus, many reflectors within each group that are masked in the condensed section in the south become quite pronounced to the north.

Most of the continuous reflectors are caused by volcanic ash layers that were cored at Site 578. Reflector $R_{2}$ is equivalent to Reflector 1-f as defined at Site 578 (see Site 578 chapter, this volume) and probably corresponds to volcanic ash Layer \#8 ( 0.475 m.y. ago). Reflector $\mathrm{R}_{3}$ is equivalent to Reflector 2-a at Site 578; this reflector does not correlate with any major observed lithologic change. The depth of $R_{3}$ corresponds to a magnetostratigraphic age of $\sim 0.975 \mathrm{~m}$.y. Reflector $\mathbf{R}_{4}$ is Reflector 3-g at Site 578; this reflector correlates with volcanic ash Layer \#50, which is $\sim 2.44$ m.y. old. At Site 578 horizons corresponding to Reflectors $R_{5}$ and $R_{6}$ are below the depth of penetration of the $3.5-\mathrm{kHz}$ echograms; hence positive correlations of these deep reflectors with volcanic ashes cored at Site 578 are not possible. Extrapolation of $R_{5}$ to Site 578 yields an inferred $R_{5}$ age of $\sim 5-6$ m.y.

\section{Bathymetry (Reflector $\mathbf{R}_{1}$ )}

The seafloor in study Area $B_{1}$ generally slopes north and ranges in depth from $5740 \mathrm{~m}$ on the southern margin of the area to $6040 \mathrm{~m}$ in the northern part (Fig. 12). Abyssal hills occur primarily in the northern half of the site survey. The maximum local relief in the study area is only $79 \mathrm{~m}$ on an abyssal hill located at $33.7^{\circ} \mathrm{N}, 152.25^{\circ} \mathrm{E}$.

The study area can be divided into three distinct bathymetric provinces: the southern Province A, with a very regular north-northeast-sloping seafloor, the central Prov- 


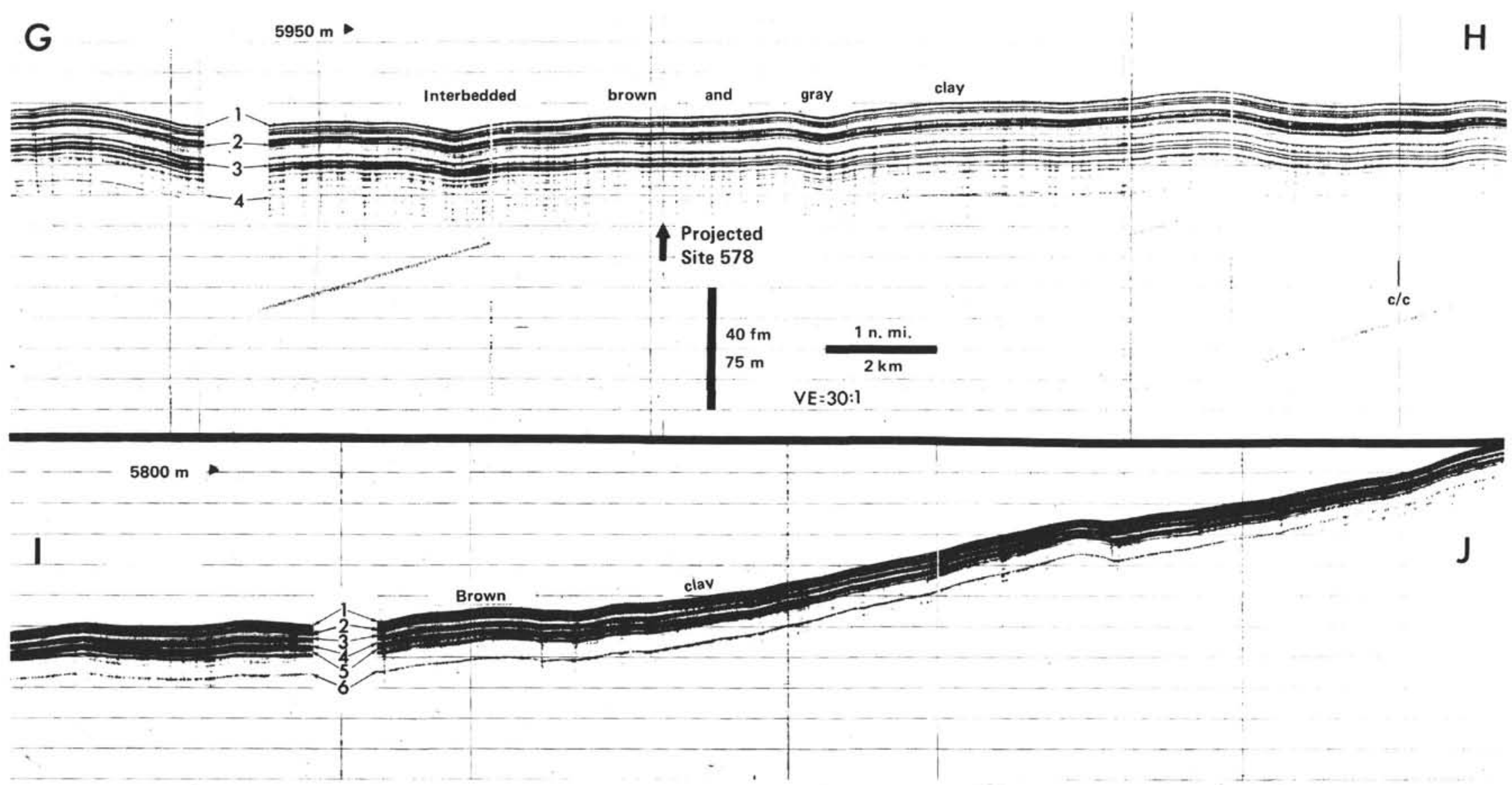

Figure 11. High-resolution seismic Profiles (3.5-kHz echograms) G-H and I-J in study Area $B_{1}$ (after Damuth et al., 1980 and Hayes et al., 1983). Profiles are located in Figure 4. Digitized reflectors are labeled and $R_{2}$ is $0.475 \mathrm{~m}$.y. old, $R_{3}$ is $0.975 \mathrm{~m}$.y. old, $R_{4}$ is $\sim 2.44 \mathrm{~m}$.y. old, and $R_{5}=\sim 5-6 \mathrm{~m}$.y. old. Profile $G-H$ was recorded in the northern part of $B_{1}$ where the sedimentation rate is relatively high, whereas Profile I-J was recorded in the southern part of $B_{1}$ where the sedimentation rate is relatively low. In Profile I-J, note the southward thinning of reflector intervals (toward J). Site 578 is projected westward onto Profile G-H. C/C = course change. Vertical exaggeration is 30:1. 


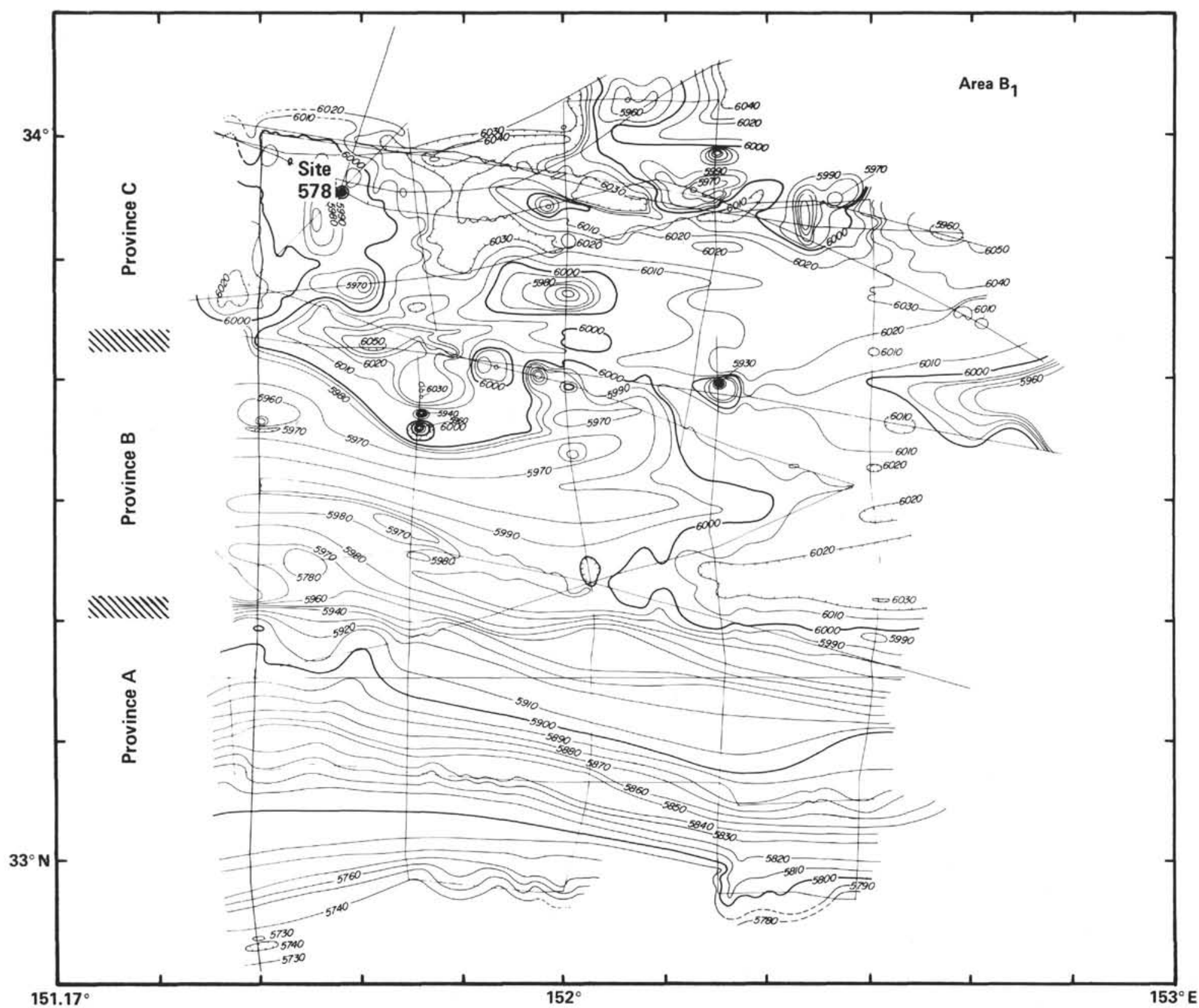

Figure 12. Bathymetry of study Area $B_{1}$. Depths are in corrected meters utilizing the correction tables of Carter (1980). Primary contour interval is $10 \mathrm{~m}$. Boundaries are noted for the approximately east-west trending bathymetric provinces. 
ince $\mathrm{B}$, with subdued ridges, troughs, and locally relatively steep slopes, and the northern Province $C$, which has many small abyssal hills (see Fig. 12 and Table 6).

The Province A/Province B boundary consists of a relatively steep, north-northeast facing slope (commonly $1-2^{\circ}$ ) with $60-70 \mathrm{~m}$ relief. In Province B, broad, low ridges and troughs generally trend west to west-northwest. The southern flanks of these ridges slope gently while the northern flanks slope steeply.

Province $\mathrm{C}$ has a large number of abyssal hills with relatively steep slopes (Table 6). Because the ship's track spacing is typically large, it is not possible in most cases to determine if the abyssal hills have a preferred orientation. In the northernmost part of the survey area, where the track spacing is smaller, abyssal hills appear to have both north-south and east-west trends. The magnetic lineations trend west-northwest throughout most of Area $\mathrm{B}_{1}$ suggesting that the west-northwest bathymetric trend is a relict fabric originally created at a spreading center active $\sim 155 \mathrm{~m}$.y. ago. The seafloor becomes younger to the north; thus, the relatively steep slopes that face north are probably surface expressions of buried fault scarps of the rift mountains. The regional seafloor gradient is opposite to that predicted by empirical age/depth cooling curves (e.g., Parsons and Sclater, 1977). The age of the seafloor at study Area $B_{1}$ predicts a relatively flat age-crustal depth curve; therefore, factors other than crustal cooling may control the regional gradient at Area $\mathrm{B}_{1}$ (e.g., bordering volcanic edifices).

\section{Intervals $\mathbf{R}_{\mathbf{1}}-\mathbf{R}_{\mathbf{2}}, \mathbf{R}_{\mathbf{2}}-\mathbf{R}_{\mathbf{3}}$, and $\mathbf{R}_{\mathbf{3}}-\mathbf{R}_{\mathbf{4}}$}

The local and regional variations in interval thicknesses and sedimentation rate are summarized in Table 7 and Figures 13 and 14. Each interval thickness within $R_{1}-R_{4}$ generally decreases northward from the southern border of study Area $B_{1}$ to a minimum value in the west central part of Province A. Interval thicknesses then increase northward to maximum values along the northern border of Area $B_{1}$ (Figs. 13 and 14). This 8- to 13fold increase in sediment accumulation in all intervals occurs over a distance of only $\sim 80 \mathrm{~km}$ (see Table 7).

Anomalously thin zones in Province A commonly occur on relatively steep, north-facing slopes (e.g., the northern border of Province A, the west central anomaly, and the southeast corner of Province A). In contrast, a zone of anomalously thick sediment is located in the east central part of Province A where the seafloor gradient is distinctly lower than the surrounding area. Some relatively steep north-facing slopes have anomalously thick

Table 6. Characteristics of bathymetric features in provinces of study Area $\mathrm{B}_{1}$.

\begin{tabular}{cccccc}
\hline & \multicolumn{2}{c}{ Local relief $(\mathrm{m})$} & & \multicolumn{2}{c}{ Local slopes $\left(^{\circ}\right)$} \\
\cline { 5 - 6 } Province & Typical & Maximum & & Typical range & Maximum range \\
\hline A & & 4 & & $0.25-0.5$ & $0.09-0.6$ \\
B & $30-40$ & $30-70$ & & $1.5-2$ & $\begin{array}{c}\text { and few 2 } \\
0.2-3\end{array}$ \\
C & $40-50$ & $10-79$ & & $0.5-2$ & $0.25-9$ \\
\hline
\end{tabular}

a Based on Figure 12.
Table 7. Seismic interval thicknesses and sedimentation rates in study Area $\mathrm{B}_{1}$.

\begin{tabular}{|c|c|c|c|c|c|c|c|}
\hline \multirow[b]{2}{*}{ Interval } & \multirow[b]{2}{*}{ Value $^{\mathrm{a}}$} & \multicolumn{2}{|c|}{ Province A } & \multicolumn{2}{|c|}{ Province B } & \multicolumn{2}{|c|}{ Province C } \\
\hline & & Typical & Maximum & Minimum & Typical & Typical & Maximum \\
\hline \multirow[t]{4}{*}{$R_{1}-R_{2}$} & A & $6-8$ & & $3-5$ & 8 & 22.5 & $28-30$ \\
\hline & B & 12.6 & 16.8 & $6.3-10.5$ & & & $59.9-63.2$ \\
\hline & C & & & & 3 & 9 & 16 \\
\hline & D & 4.2 & & & 6.3 & 18.9 & 33.7 \\
\hline \multirow{4}{*}{$R_{2}-R_{3}$} & A & $6-8$ & & $2-4$ & 10.5 & 20 & $24-26$ \\
\hline & B & $12-19$ & & $4-8$ & & & $48-52$ \\
\hline & C & $2-3$ & 4 & & $2-3$ & $2^{b}$ & 7 \\
\hline & D & $4-6$ & 8 & & $4-6$ & 4 & 14 \\
\hline \multirow{4}{*}{$R_{3}-R_{4}$} & A & $7-8$ & & $3-5$ & & & $28-29$ \\
\hline & B & $4.7-5.4$ & & $2.0-3.4$ & & & $18.9-19.6$ \\
\hline & C & 1 & 2 & & 3 & $2^{b}$ & 7 \\
\hline & D & 0.68 & 1.35 & & 2 & 4 & 14 \\
\hline
\end{tabular}

${ }^{a} \mathrm{~A}=$ regional thickness of reflector interval $(\mathrm{m}), \mathrm{B}=$ regional sedimentation rate $(\mathrm{mm} /$ $1000 \mathrm{yr}$.), $\mathrm{C}=$ local thickness variations $(\mathrm{m}), \mathrm{D}=$ local sedimentation rate variations ( $\mathrm{mm} / 1000 \mathrm{yr}$.$) .$

b Very local anomalies.

$\mathrm{R}_{1}-\mathrm{R}_{2}$ sediment sections (e.g., $33.13^{\circ} \mathrm{N}, 152.23^{\circ} \mathrm{E}$ ) and may result from mass wasting. In the southern part of Province A, most of the north-south tracks display similar $R_{2}-R_{3}$ and $R_{3}-R_{4}$ variations along track that appear to form east-west trending waves of 2 - to $3-\mathrm{km}$ wavelengths and amplitudes of $\leq 2 \mathrm{~m}$. Bottom-water flow that is independent of the local slope may cause some of these local variations. The sediment-interval thickness that characterizes Province A extends southward only to a large abyssal hill at $32.75^{\circ} \mathrm{W}, 151.50^{\circ} \mathrm{E}$ (just south of study Area $\mathrm{B}_{1}$ ). Southward from this abyssal hill to at least $32^{\circ} \mathrm{N}$, each of the intervals $R_{1}-R_{2}, R_{2}-R_{3}$, and $R_{3}$ $R_{4}$ is consistently $\sim 5 \mathrm{~m}$, while to the north of this abyssal hill, interval thicknesses increase abruptly to $\sim 8 \mathrm{~m}$.

In Province B most of the anomalously thick zones occur on south-facing slopes, while the steeper northfacing slopes generally have anomalously thin zones (e.g., the northwest boundary of Province B). Other zones of thick sediment occur on gentle north-facing slopes, on tops of ridges, and in small basins.

In Province $\mathrm{C}$, the regional thickness increases from south to north by a factor of more than two, but this gradient is less uniform than in the other provinces. North slopes of abyssal hills and ridges generally have anomalously thin zones, south slopes have thick zones. A few abyssal hills exhibit the opposite relationship. East slopes have primarily thick zones and west slopes have thin zones for intervals $R_{1}-R_{2}$ and $R_{2}-R_{3}$. Other thin zones occur on tops of ridges and in gaps.

The general case of north and west slopes/thin sediment indicate bottom-water flow to the south or east, but the anomalous abyssal hills provide a warning that the bottom-water circulation may be more complicated or our data may be inadequate. We view the rapid increase in sedimentation rate as delineating the southern boundary of a major sediment drift deposit. The extent and cause of this sediment drift remain uncertain. The drift extends north to at least the northern margin of the study area $\left(34.3^{\circ} \mathrm{N}\right)$ and possibly much farther.

Although most major $\mathbf{R}_{3}-\mathrm{R}_{4}$ anomalies are similar in extent to those in intervals $R_{1}-R_{2}$ and $R_{2}-R_{3}$, some are different. In Province A, the southern part of the westcentral thin zone is much smaller for $R_{3}-R_{4}$ times than 
for later times. Similarly, the northern part of the eastcentral $R_{3}-R_{4}$ thick zone is not observed for $R_{1}-R_{3}$. Thus, the central area of Province $A$ appears to have experienced a slightly faster bottom-water flow during $R_{1}-$ $\mathrm{R}_{3}$ times than during $\mathrm{R}_{3}-\mathrm{R}_{4}$ times. In contrast, the width of the thin zone along the northwest boundary of Province $B$ contracted by at least $5 \mathrm{~km}$ for $R_{3}-R_{4}$ to $R_{1}-R_{3}$ time. This observation suggests that the bottom-water flow decreased from $R_{3}-R_{4}$ to $R_{1}-R_{3}$ in Province $B$. That the inferred sense of change of bottom-water flow is opposite for adjacent provinces indicates that anomalous thicknesses can be controlled in Area $B_{1}$ by very local flow conditions.

In Provinces B and C, a few thickness anomalies appear to shift south from $R_{3}-R_{4}$ times to $R_{2}-R_{3}$ times (e.g., the thick zone at $33.5^{\circ} \mathrm{N}, 152.3^{\circ} \mathrm{E}$ shifts $2 \mathrm{~km}$ downslope). In contrast, the small anomaly at $33.7^{\circ} \mathrm{N}$, $152.2^{\circ} \mathrm{E}$ appears to shift north (upslope) $1 \mathrm{~km}$ from $\mathrm{R}_{3}$ $R_{4}$ times to $R_{2}-R_{3}$ times. These observations also suggest that the flow conditions varied on a very local scale from $R_{3}-R_{4}$ times to $R_{2}-R_{3}$ times.

\section{Intervals $\mathbf{R}_{\mathbf{4}}-\mathbf{R}_{\mathbf{5}}$ and $\mathbf{R}_{\mathbf{5}}-\mathbf{R}_{\mathbf{6}}$}

Reflectors $R_{5}$ and $R_{6}$ are too deep to be observed on $3.5-\mathrm{kHz}$ echograms in Province $\mathrm{C}$ and the north and eastern parts of Province B (Fig. 13D and 13E). However, the regional variations of intervals $R_{4}-R_{5}$ and $R_{5}-$ $R_{6}$ that are observed suggest that the sedimentation during $\mathbf{R}_{\mathbf{4}}-\mathbf{R}_{6}$ times was similar to that in later times (Fig. 14). The regional thickness for interval $R_{4}-R_{5}$ and $R_{5}-$ $R_{6}$ decreased by about a factor of two from the southern boundary of Province $B_{1}$ to the west-central part of Province $\mathrm{A}$. The regional thickness then increases rapidly northward for both intervals. The thickness of $R_{5}-R_{6}$, $R_{4}-R_{5}$, and $R_{3}-R_{4}$ all increase by about $100 \%$ over the same distance of only $\sim 12 \mathrm{~km}$. It is therefore probable that like $R_{3}-R_{4}$, the $R_{5}-R_{6}$ and $R_{4}-R_{5}$ interval thicknesses continue to increase northward beyond the northern limits of their observation.

In Province $\mathbf{A}$, east-west trending, prominent thin zones occur on relatively steep, north-facing slopes. The major examples occur along the northern boundary of Province $\mathrm{A}$ and in the zone extending from the west central to the southeast corner of Province A. In contrast, a thick zone lying between these two thin zones is most prominent over the areas of relatively low seafloor gradients in the east-central part of Province A. As in the overlying units, WNW-trending waves in the $\mathrm{R}_{4}-\mathrm{R}_{6}$ interval thicknesses occur along the southern part of Province $\mathrm{A}$ with $\sim 1 \mathrm{~m}$ amplitude and $1.5-$ to $2-\mathrm{km}$ wavelengths. The southern extent of the major variations of $R_{4}-R_{6}$ characteristic of Province $A$ is marked by the abyssal hill just south of Area $B_{1}$ for interval $R_{5}-R_{6}$ and is $\sim 14 \mathrm{~km}$ south of the abyssal hill for $R_{4}-R_{5}$.

In Province B, spatially prominent thin zones occur on relatively steep north-facing slopes (e.g., $R_{4}-R_{5}$ : north flank of the ridge from $33.5^{\circ} \mathrm{N}, 151.5^{\circ} \mathrm{E}$ to $33.4^{\circ} \mathrm{N}$, $\sim 152^{\circ} \mathrm{E}$ ). Well-developed thick zones occur on southfacing slopes of abyssal hills and, for $R_{4}-R_{5}$, on tops of abyssal hills and in areas of low seafloor gradients.
In Province $\mathrm{C}, \mathrm{R}_{5}$ is observed only at the two abyssal hills located at $33.6^{\circ} \mathrm{N}, 152.75^{\circ} \mathrm{E}$, where thick zones occur on the south sides of the hills.

Although intervals $R_{4}-R_{5}$ and $R_{5}-R_{6}$ are observed over a limited extent, the pattern of anomalies is similar to that of the more extensive, overlying units (e.g., Fig. 14), suggesting bottom-water flow to the south or east for $\mathbf{R}_{4}-\mathrm{R}_{6}$ times. The major flow components appear to have remained spatially stable from $R_{4}-R_{6}$ times to $R_{3}-$ $R_{4}$ times because the major sediment drift in central and northern $\mathrm{B}_{1}$, as well as most other anomalies, is located in the same area for these reflector intervals. Locally the southern boundaries of the thin zones migrated south through time $\left(\mathbf{R}_{5}-\mathbf{R}_{6}\right.$ to $\mathbf{R}_{\mathbf{4}}-\mathbf{R}_{5}$ times), expanding the thin zones at the expense of the thick zones. The expanding thin zones might suggest that the strength of the bottom-water circulation increased locally from $R_{5}-R_{6}$ times to $R_{4}-R_{5}$ times.

\section{SUMMARY AND CONCLUSIONS}

The bathymetry in Area $\mathrm{E}_{2}$ has a northwest-southeast lineation that is parallel to the magnetic lineations and may be a consequence of original rift tectonics. The local relief is generally $\leq 50 \mathrm{~m}$ except in the southeastern part (bathymetric Province B) and along the northern and southern borders of Area $E_{2}$, where relief up to 305 $\mathrm{m}$ is observed.

Two continuous, sharp reflectors in the upper part of the $3.5-\mathrm{kHz}$ seismic section are observed throughout the area; the upper reflector $\left(\mathrm{R}_{2}\right)$ corresponds to an $\sim 1.3$ m.y. old volcanic ash layer and the other reflector $\left(R_{3}\right)$ is $\sim 7.2$ m.y. old (Fig. 6). Isopach maps of these seismic intervals reveal local variations in sediment thickness that can be attributed to sediment slides and probably also to variations in the bottom-water flow. Localized areas with either diminished or increased sedimentation occur commonly on northeast slopes. However, on the steep slopes of abyssal hills and ridges, the northeast slopes generally show anomalously thin sediments. This relationship could arise from any pattern of bottom-water flow with a strong southerly component (with a range from southeast to southwest). Sediment slide deposits appear to be less prominent in the 1.3 to $7.3 \mathrm{~m}$.y. ago interval than in more recent times. Although sediment slides are apparent in association with some small, localized bathymetric highs, such deposits occupy only a very minor fraction of the study area. The overall pattern of recent sedimentation, as revealed by the $3.5-\mathrm{kHz}$ echograms and piston cores, indicates that Area $\mathrm{E}_{2}$ records a low energy and remarkably stable sedimentation environment.

Reflector $\mathrm{R}_{4}$ is discontinuous throughout the study area and where observed, may not always represent the same geologic horizons. At Site 576, the age of $\mathbf{R}_{\mathbf{4}}$ is $\sim 25 \mathrm{~m}$.y. The most distinct difference between seismic interval $\mathbf{R}_{3}-\mathbf{R}_{\mathbf{4}}$ and all other digitized seismic intervals is the lack of "mini-moats" along the margins of troughs. This may indicate a decrease in the intensity of bottomwater flow during the period from $\sim 7.2$ to $\sim 2.5$ m.y. ago. However, the overall relationship between seafloor 


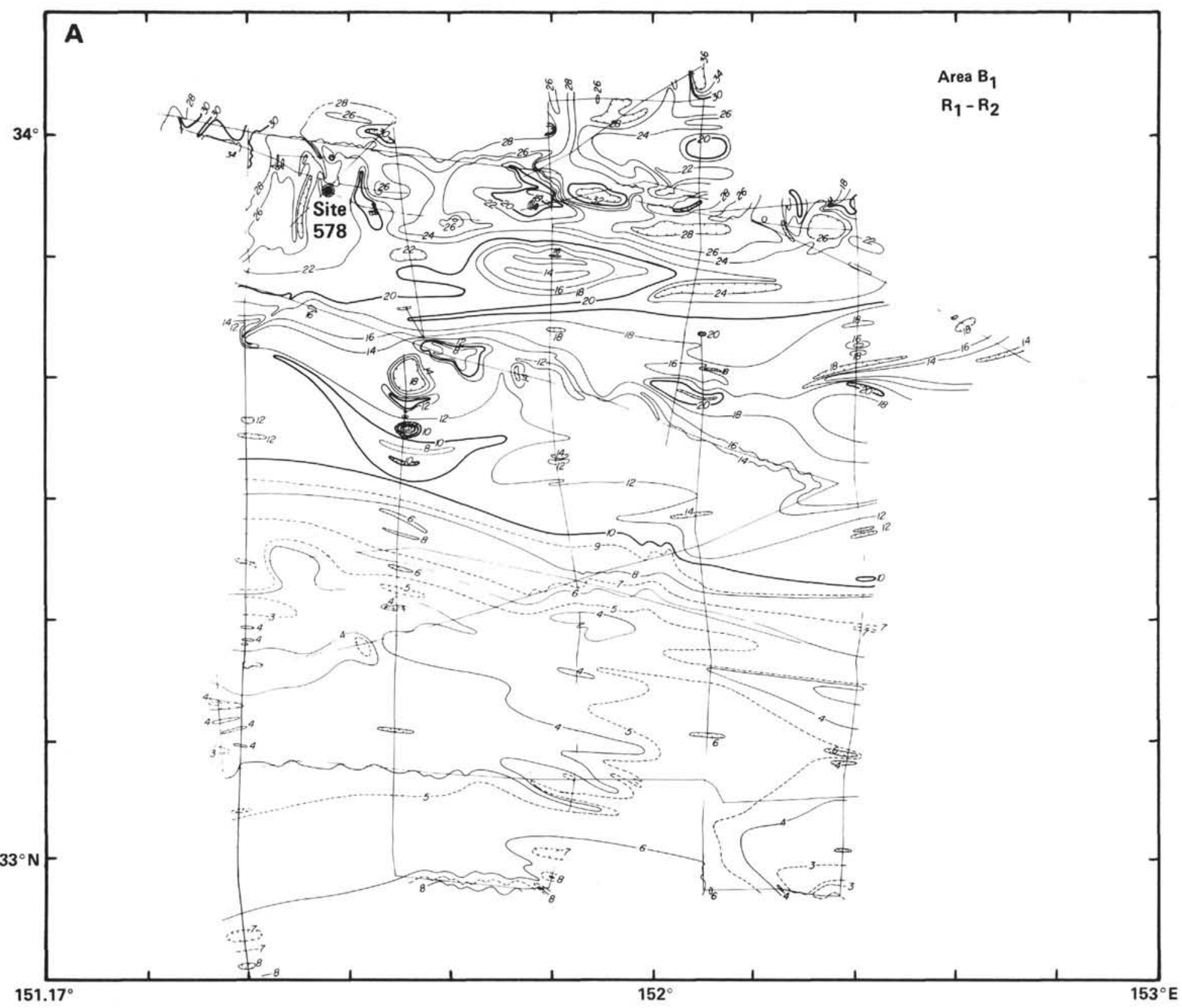




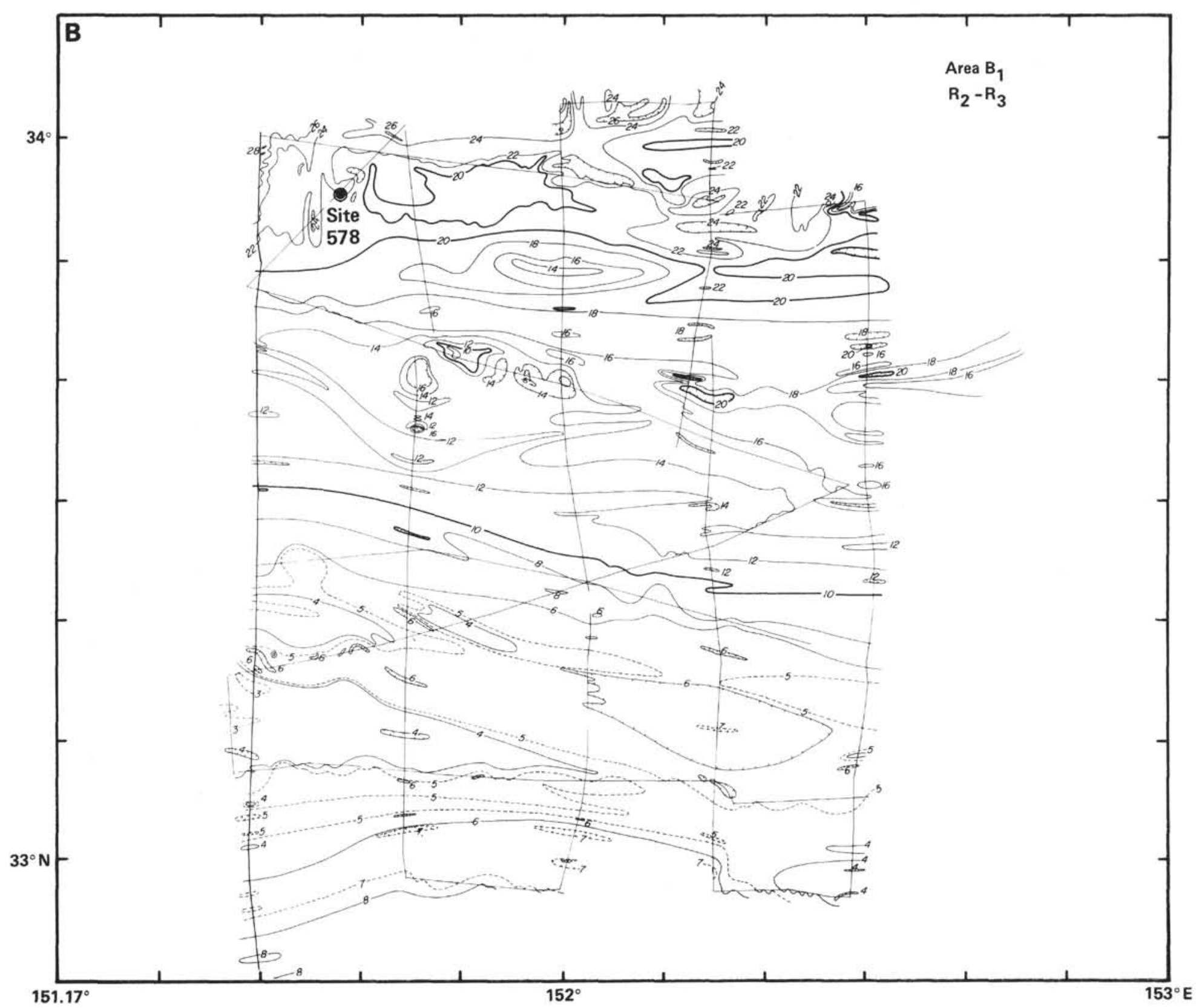

Figure 13. Isopach maps for the various 3.5-kHz seismic reflector intervals in study Area $B_{1}$. Figure $13 A$ : interval $R_{1}-R_{2}\left(0-0.475\right.$ m.y.), Figure $13 B$ : interval $R_{2}-R_{3}$ (0.475-0.975 m.y.), Figure 13C: interval $R_{3}-R_{4}\left(0.975-2.44\right.$ m.y.), Figure 13D: interval $R_{4}-R_{5}\left(2.44-\sim 5-6\right.$ m.y.), Figure 13E: interval $R_{5}-R_{6}$. 







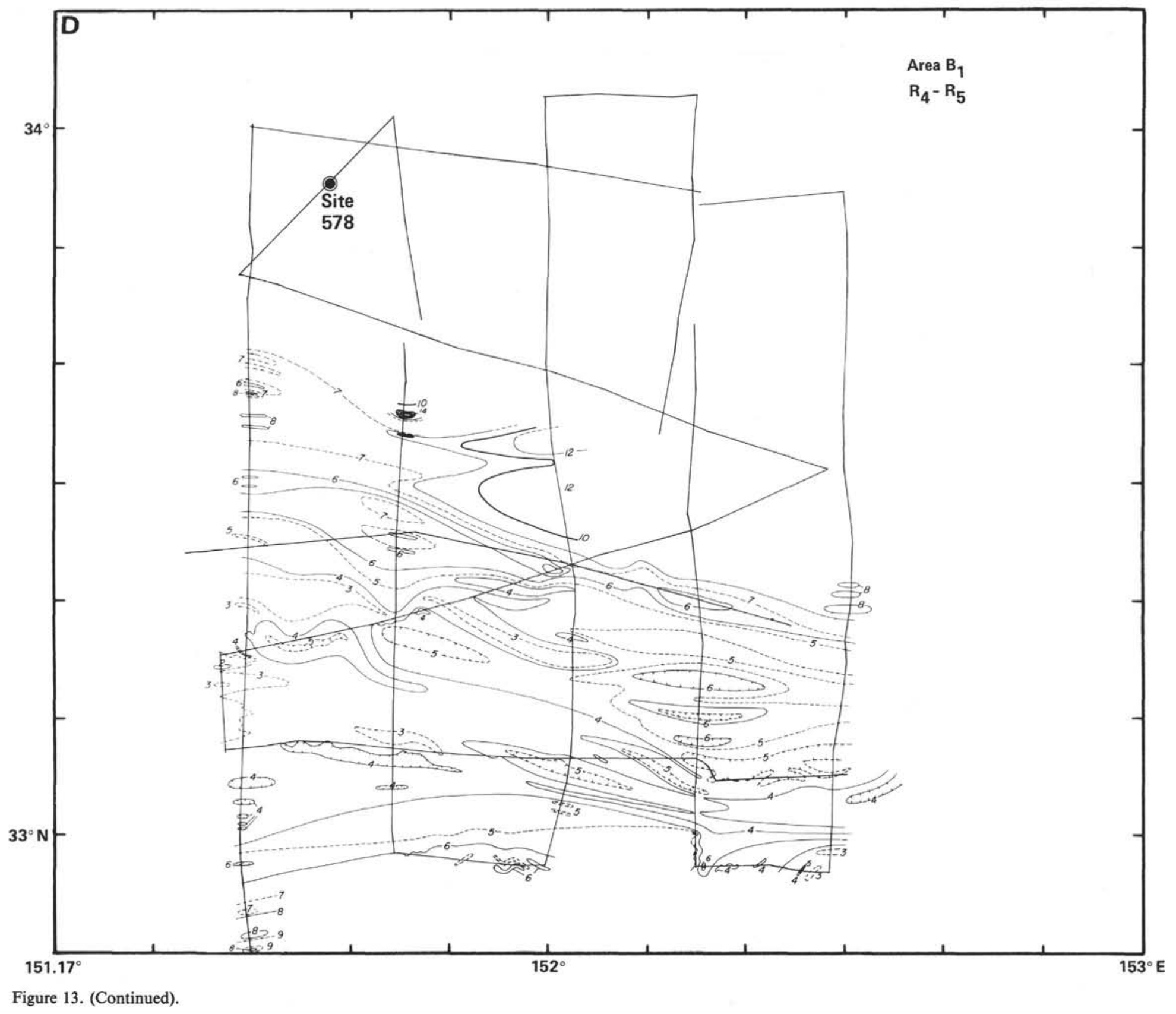

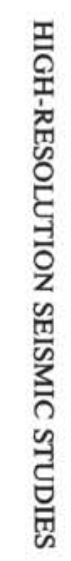




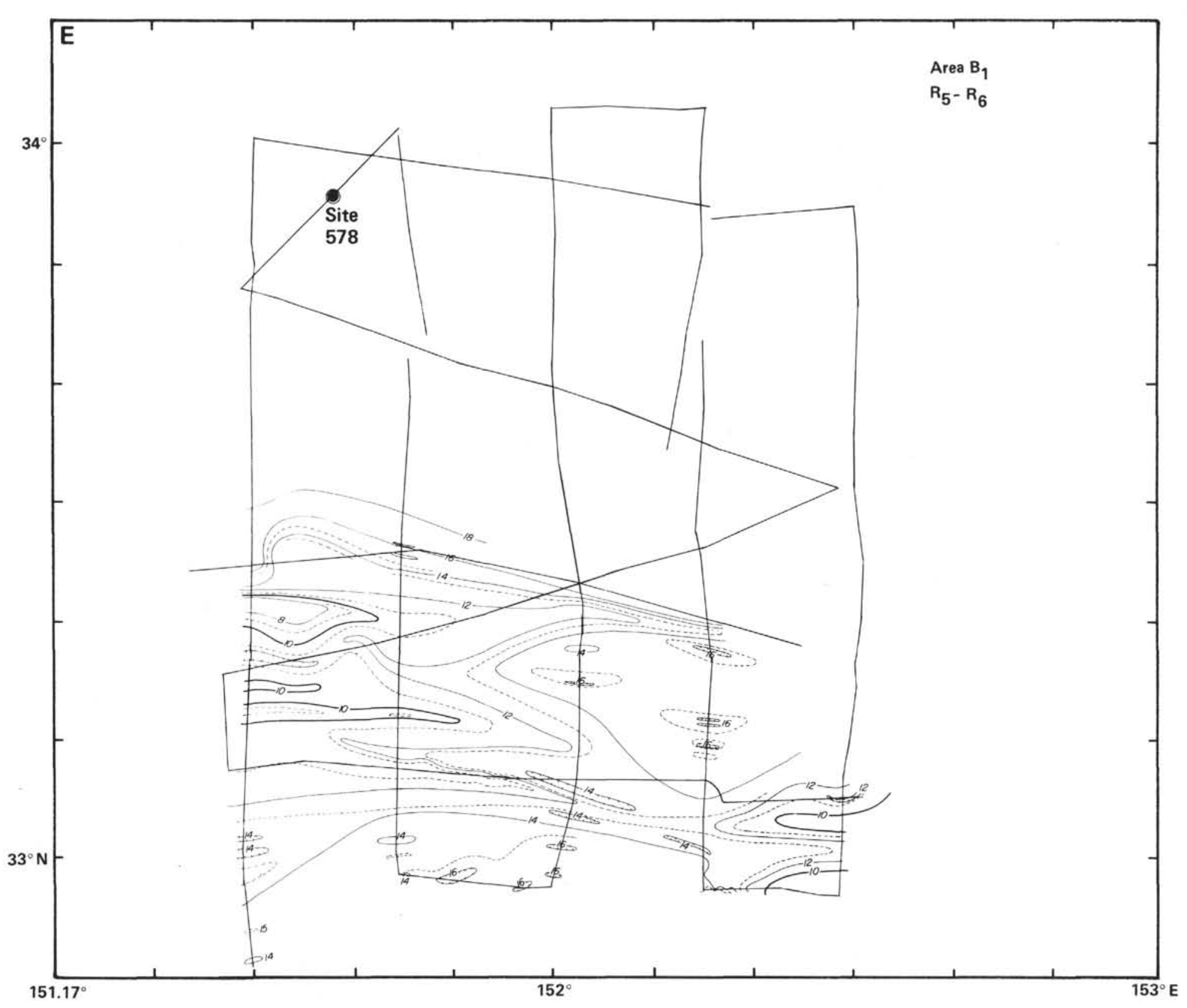

Figure 13. (Continued). 


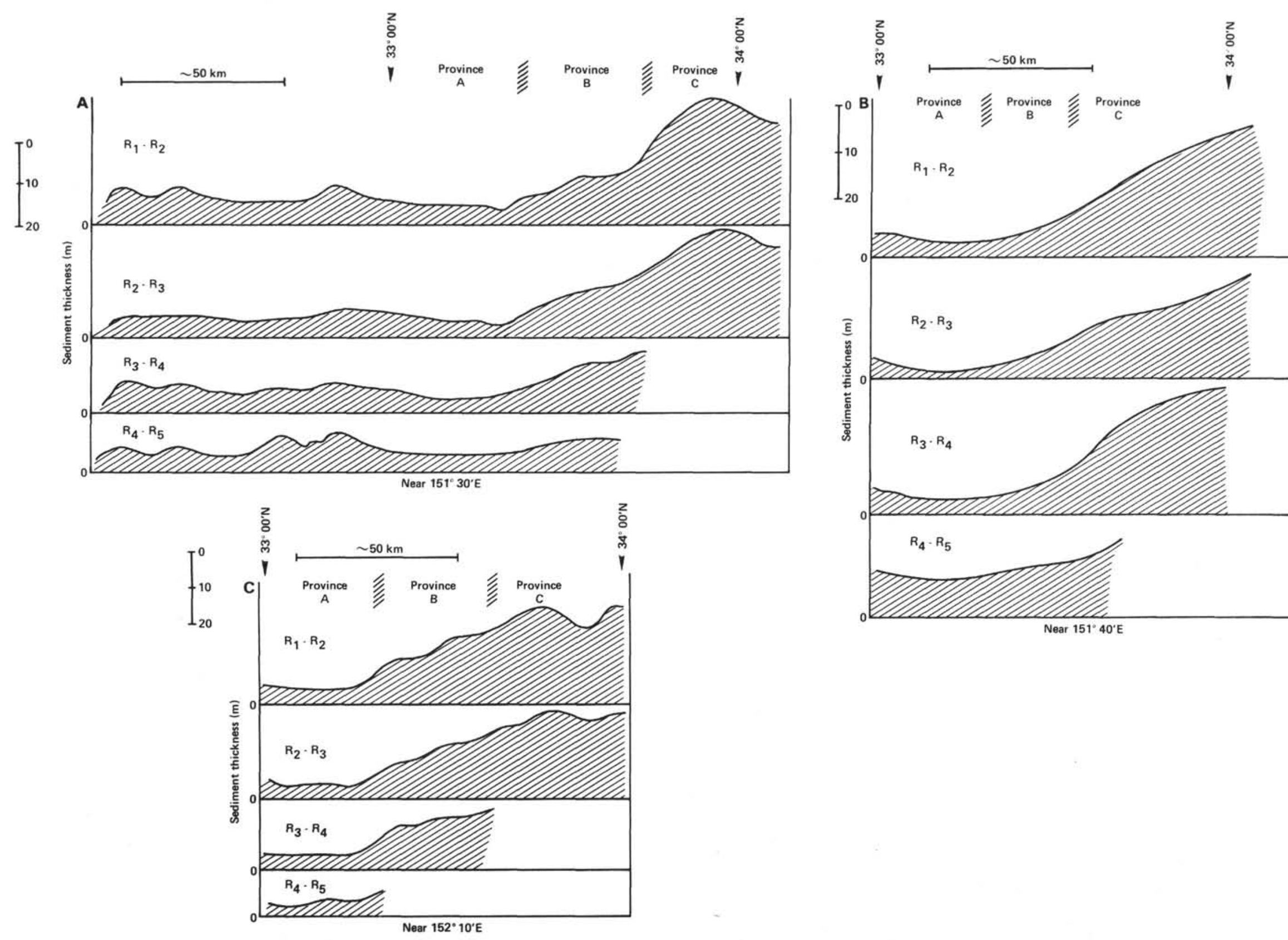


relief and anomalous sediment accumulation rates in $R_{3}-$ $\mathrm{R}_{\mathbf{4}}$ is similar to that observed in the overlying intervals. Thus, direction of the bottom-water flow probably remained roughly constant for the past 25 m.y.

Acoustic basement $\left(R_{5}\right)$ on the $3.5-\mathrm{kHz}$ echograms (Fig. 6) corresponds to $\sim 70$ m.y. old carbonate turbidites and pelagic sediments interbedded with brown clay in "basement" lows; pelagic carbonate or chert probably mark the "basement" highs. Seismic interval $R_{4}-R_{5}$ exhibits thin zones along the margins of troughs, suggesting increased bottom-water flow compared to $R_{3}-R_{4}$ time. These thin zones generally lie along the northeast margins of troughs and could result from northward bottom-water flow. However, the larger population of observations from entire interval $R_{3}-R_{5}$ is inconsistent with this hypothesis, and therefore any inference of northward bottom-water flow during the interval $R_{4}-R_{5}$ should be regarded as very tentative. The integrated seismic interval, $R_{3}-R_{5}$, shows relationships of seafloor slope to anomalous sediment accumulation similar to those of the overlying units. It is probable, therefore, that the overall circulation pattern of bottom-water at Area $\mathrm{E}_{2}$ has remained relatively stable for the past $70 \mathrm{~m}$.y. The inferred southward flow is contrary to the regional flow direction thought to exist for the PBW in this area (Mantyla, 1975). This apparent contradiction suggests either that accurate regional flow directions cannot be ascertained from local, small variations in sediment-accumulation rate or that local bottom-water flow in this area was counter to the overall PBW circulation.

The dramatic thinning of all seismic intervals in the northeast corner of study Area $E_{2}$ suggests that bottomwater flow was accelerated in this area. This hypothesis is consistent with the Area $\mathrm{E}_{2}$ piston cores, which reveal coarser sediments in this area (generally silt size in Core 51 versus silty clay and clayey silt in all other cores, see Table 1). The consistent sedimentation pattern for the past $70 \mathrm{~m}$.y. suggests that flow here has been controlled by bathymetric features. North and east of Area $E_{2}$, a barrier to the northeastward flow of PBW is formed by the intersection of northwest to southeast trending bathymetric highs with the Shatsky Rise (fig. 2 in Damuth et al., 1983). An apparent gap in this barrier occurs at $32.83^{\circ} \mathrm{N}, 166.83^{\circ} \mathrm{E}$; northeast of this gap the seafloor returns echoes typical of areas with accelerated bottomwater flow (Damuth et al., 1983). The sediment thinning at the northeast corner of Area $\mathrm{E}_{2}$ may be the expression of constricted and accelerated bottom-water flow through this gap. The bathymetric barrier may also cause a local bottom "gyre" within the generally northeast flowing PBW and could explain the apparent southerly flow directions at Area $\mathrm{E}_{2}$.

At study Area $\mathrm{B}_{1}$, the bathymetry is extremely subdued in Province A, with a maximum local relief of only $4 \mathrm{~m}$. In the remainder of Area $B_{1}$, abyssal hills and ridges occur with a maximum local relief of $79 \mathrm{~m}$. The east-west trend of many of the bathymetric features is parallel to the magnetic lineations, suggesting that much of the bathymetry is related to rifting phenomena. The linear, steeper slopes generally face north toward younger seafloor and may be surface expressions of buried fault scarps generated at rift mountains. The regional gradient of the seafloor at Area $B_{1}$ slopes to the north toward younger seafloor (opposite to slope predicted by empirical age/depth cooling curves).

The $3.5-\mathrm{kHz}$ seismic section in Area $\mathbf{B}_{1}$ contains several continuous, parallel reflectors that correspond to volcanic ash layers. All seismic intervals defined by these reflectors exhibit similar regional and local variations in the sediment-accumulation rate. The thickness of reflector interval $R_{1}-R_{2}(0-0.475$ m.y. ago) shows a dramatic 10 -fold increase from the center of Area $B_{1}$ to its northern border, a distance of only $80 \mathrm{~km}$. Over the same distance, interval $\mathrm{R}_{2}-\mathrm{R}_{4}$ thickness (0.975-2.44 m.y. ago) increases by eight times (Fig. 14). Intervals $R_{4}-R_{5}$ and $R_{5}-R_{6}$ show similar increases where observed. This sharp gradient in sedimentation rates appears to mark the boundary between the two major regional sediment provinces in the Northwest Pacific Basin. These provinces are distinguished by both sediment thickness and type (Table 1 and Fig. 14). Northward from the boundary, the sedimentation rate remains high to near the Kuril Trench. For example, $500 \mathrm{~km}$ north of Site 578, at Site 579 , the sedimentation rate is comparable to that found at Site 578. Southward from the boundary, the sedimentation rate remains low to at least $31^{\circ} \mathrm{N}$.

The cause of the abrupt change in sedimentation rate is an enigma. The southern border of the Kuroshio Current is presently located over study Area $B_{1}$. However, this surface current alone cannot be the direct cause of the abrupt sedimentation rate change because it did not remain fixed in its present position during Pleistocene glacials and interglacials. We therefore believe that bottom-water flow directed by bathymetric features has persistently localized and accentuated any expected "normal" gradient in sedimentation rate.

We have attempted to determine the flow direction and relative flow strength from the relationship between seafloor slope and variations in sedimentation rate. A moat on the south side of a major abyssal hill at $32.75^{\circ} \mathrm{N}$, $151.50^{\circ} \mathrm{E}$ (south of study Area $\mathrm{B}_{1}$ ) clearly suggests bottom-water flow to the north or west. A northward flow is consistent with the proposed flow of the western branch of the PBW (Mantyla, 1975). However, within study Area $B_{1}$, all seismic intervals typically exhibit anomalously thin zones on north-facing slopes and thick zones on southfacing slopes. These relationships suggest bottom-water flow to the east or south. The east-west strike of the sharp sedimentation "front" suggests that eastward bottom-water flow is more plausible. Eastward flow is not in accord with the proposed regional northward flow of PBW. Either a local bottom "gyre" operated in the immediate area of $B_{1}$ or our observed sedimentation rate variations are not good indicators of bottom-water flow. A long-term current instrument moored at $4000 \mathrm{~m}$ depth at $33.77^{\circ} \mathrm{N}, 151.98^{\circ} \mathrm{E}(\# 7003$, Schmitz et al., 1982) suggests that eastward anù southward flow maxima predominate at this location, confirming the inferred flow direction and "gyre."

Although most of the zones of anomalous sedimentation remain spatially'fixed through time, the positions of some anomalous zones change with time, suggesting 
waxing and waning of the bottom current. The predominant change in bottom-water flow appears to have occurred during $R_{4}-R_{5}$ times ( 2.44 to 5-6 m.y. ago). It was only during this time interval that the southern boundaries of thin zones migrated significantly southward, enlarging their area. Thus the inferred higher bottom-water velocity acting during $\mathbf{R}_{\mathbf{4}}-\mathrm{R}_{\mathbf{5}}$ times did not persist into $R_{3}-R_{4}$ times. At Site 578 the sedimentation rate, computed from paleomagnetics and paleontology, increases dramatically at about $2.5 \mathrm{~m}$.y. ago and remains high to the present (see Site 578 chapter, this volume), and independently argues for a higher velocity bottom current in earlier times. At study Area $E_{2}$, the velocity of the bottom water increased at $R_{3}$ times $(\sim 7.2$ m.y. ago) but the duration of this increase is unknown. The gross similarity in the timing of bottom-water velocity changes at both Sites 576 and 578 suggests that in the northwest Pacific Basin the eastern and western branches of the PBW have experienced roughly contemporaneous perturbations.

\section{ACKNOWLEDGMENTS}

We thank the officers, crew, and scientists aboard the Vema and Glomar Challenger for able assistance in gathering the data presented herein. We acknowledge the important contribution of R. Flood, M. Coffin, and J. Kostecki during Vema Cruise V36-12. Alison Gold and Norma Iturrino assisted in the digitization of the seismic records and David Johnson drafted most of the figures. R. Flood, E. Laine, and A. Wright critically reviewed the manuscript and provided many helpful suggestions. Doris Millholland and Carol Elevitch typed the manuscript. This study was supported by Sandia Contract No. SL475693.

\section{REFERENCES}

Carter, D. J. T., 1980. Echo-Sounding Correction Tables: Taunton, England (Hydrographic Dept., Ministry of Defense).

Chase, T. E., Menard, H. W., and Mammerickx, J., 1971. Topography of the North Pacific. Scripps Inst. Oceanogr., Inst. Mar. Resources, Tech. Rept. Ser., TR-17.

Craig, H., and Gordon, A. L., 1965. Isotopic oceanography: Deuterium and oxygen 18 variations in the ocean and the marine atmosphere. Mar. Geochem., Proc. Symp., Univ. Rhode Isl., Narragansett Mar. Lab., Occas. Publ., 3:277-374.

Damuth, J. E., Jacobi, R. D., Flood, R. D., and Hayes, D. E., 1980. Evaluation of the North Pacific subseabed for disposal of high-level nuclear waste. III. Preliminary results of geological/geophysical surveys of three $1^{\circ} \times 1^{\circ}$ candidate disposal sites. Trans. Am. Geophys. Union, 61:989. (Abstract)

Damuth, J. E., Jacobi, R. D., and Hayes, D. E., 1983. Sedimentation processes in the Northwest Pacific Basin revealed by echo-character mapping studies. Geol. Soc. Am. Bull., 94:381-395.

Gordon, A. L., and Gerard, R. D., 1970. North Pacific bottom potential temperature. In Hays, J. D. (Ed.), Geological Investigations of the North Pacific. Mem. Geol. Soc. Am., 126:23-39.

Hayes, D. E., Damuth, J. E., Jacobi, R. D., and Flood, R. D., 1982. Analysis of geological and geophysical data from study locations $C_{1}, B_{1}$, and $E_{2}$ in the Northwest PAC 1 study region. In Hinga, $K$. R. (Ed.), Subseabed Disposal Program Annual Report January to September 1981 (Vol. 2, Pt. 1): Albuquerque (Sandia National Laboratories), 191-206.
1983. Analysis of geological and geophysical data from study locations $C_{1}, B_{1}$, and $E_{2}$ in the northwest PAC 1 study region. In Shephard, L. (Ed.), 1982 Subseabed Disposal Program Annual Report: Site Assessment October 1981 to September 1982: Albuquerque (Sandia National Laboratories) Sandia Report SAND82-2711, pp. 17-43.

Hays, J. D., and Ninkovich, D., 1970. North Pacific deep-sea ash chronology and age of present Aleutian underthrusting. In Hays, J. D. (Ed.), Geological Investigations of the North Pacific. Mem. Geol. Soc. Am., 126:263-290.

Heath, G. R., 1981. Site qualitıcation and multıbarrier assessment, 1980. Appendix R In Hinga, K. R. (Ed.), Subseabed Disposal Program Annual Report January to December 1980 (Vol. II, Pt. 2), Albuquerque (Sandia National Laboratories), Rept. SAND81-1095, pp. 50-145.

Horn, D. R., Delach, M. H., and Horn, B. M., 1969. Distribution of volcanic ash layers and turbidites in the North Pacific. Geol. Soc. Am. Bull., 80:1715-1724.

Horn, D. R., Horn, B. M., and Delach, M. N., 1970. Sedimentary provinces of the North Pacific. In Hays, J. D. (Ed.), Geological Investigations of the North Pacific. Mem. Geol. Soc. Am., 126: $1-21$.

Iwabuchi, Y., 1979. General Bathymetric Chart of the Oceans (GEB$C O$ ): Ottawa, Canada (Canadian Hydrographic Service), Map 506.

Larson, R. L., Cande, S. C., Dewey, J. F., Golovchenko, X., Haxby, W. F., LaBrecque, J. L., and Pitman, W. C. III, 1983. The bedrock geology of the world. Trans. Am. Geophys. Union, 64:863. (Abstract)

Larson, R. L., and Hilde, T. W. C., 1975. A revised time scale of magnetic reversals for the Early Cretaceous and Late Jurassic. J. Geophys. Res., 80:2586-2594.

Lonsdale, P., and Smith, S. M., 1980. "Lower insular rise hills" shaped by a bottom boundary current in the Mid-Pacific. Mar. Geol., 34: M19-M25.

Lonsdale, P., and Spiess, F. N., 1977. Abyssal bedforms explored with a deeply-towed instrument package. Mar. Geol., 23:57-75.

Mantyla, A. W., 1975. On the potential temperature in the abyssal Pacific Ocean. J. Mar. Res., 33:341-354.

Ninkovich, D., and Robertson, J. H., 1975. Volcanogenic effects on the rates of deposition of sediments in the Northwest Pacific Ocean. Earth Planet. Sci. Lett., 27:127-136.

Parsons, B., and Sclater, J. G., 1977. An analysis of the variation of ocean floor bathymetry and heat flow with age. J. Geophys. Res., $82: 803-827$

Reid, J. L., and Lonsdale, P. F., 1974. On the flow of water through the Samoan Passage. J. Phys. Oceanogr., 4:58-73.

Reid, J. L., and Lynn, R. J., 1971. On the influence of the Norwegian-Greenland and Weddell Seas upon the bottom waters of the Indian and Pacific Oceans. Deep Sea Res., 19:1063-1088.

Roberts, O. G., Hogg, N. G., Bishop, D. G., and Flewellen, C. G., 1974. Sediment distribution around a moated seamount in the Rockall Trough. Deep Sea Res., 21:175-184.

Schmitz, W. J., Niiler, P. P., Bernstein, R. L., and Holland, W. R., 1982. Recent long-term moored instrument observations in the Western North Pacific. J. Geophys. Res., 87:9425-9440.

Udintsev, G., 1980. General bathymetric chart of the oceans (GEBCO): Ottawa, Canada (Canadian Hydrographic Service), Map 5-02.

Warren, B. A., 1973. Transpacific hydrographic sections at lats. $43^{\circ} \mathrm{S}$ and $28^{\circ} \mathrm{S}$ : the SCORPIO Expedition-II. Deep water. Deep Sea Res., 20:9-38.

Date of Initial Receipt: 27 February 1984

Date of Acceptance: 26 August 1984 